\title{
Düzenleyici Kurumların Türk Spor Kulüplerinde Entelektüel Sermaye Oluşumuna Etkileri ve Bir Araştırma
}

\author{
The Effects of Regulatory Organizations on the Formation of Intellectual Capital in \\ Turkish Sports
}

Ali ALAGÖZ*

Yasin GÜLER $R^{* *}$

$\ddot{O} Z$

Bu çalışmanın amacı BIST'de işlem gören spor kulüplerinin entelektüel sermaye değerlerini ölçerek, spor kulüplerinin mali yapısını düzenleyen ve denetleyen kurumlardan biri olan UEFA'nın ortaya koyduğu Finansal Fair Play kriterlerinin, kulüplerin entelektüel sermayeleri üzerinde etkilerini ölçmektir.

Bu amaç ışı̆̆ında çalışma üç bölümden oluşmuştur. Birinci bölümde entelektüel sermaye hakkında genel bilgi verilmiş, ikinci bölümde konuyla ilgili literatüre yer verilmiş, üçüncü bölümü olan uygulama kısmında, entelektüel sermayeyi işletme bazında ölçen Piyasa Değeri ve Defter Değeri, Tobin’in Q Değeri, Hesaplanmış Maddi Olmayan Değer ve Ekonomik Katma Değer yöntemlerin her biri ile spor kulüplerinin son 10 yıllık ES değerleri ve tutarları bulunmuştur. Hesaplamalardan elde edilen veriler FFP kapsamında değerlendirilerek çalışma sonlandırılmıştır.

ANAHTAR KELIMELER

Entelektüel Sermaye, Spor Kulüpleri, Finansal Fair Play

\begin{abstract}
The aim of this study is to measure the effects of the Financial Fair Play criteria, which is determined by one of the institutions regulating and controlling the financial structure of sports clubs, UEFA, on the intellectual capital of the clubs by mesauring the intellectual capital values of sports clubs traded on BIST.

Regarding this purpose, the study consists of three parts.In the first part;general information about intellectual capital is given, in the second part; the related literature is given and in the third,application, part;ES values of the last 10 years of sport clubs and amounts were found with each of Market Value and Book Value, Tobin's Q Value, Calculated Intangible Value and Economic Added Value methods that measure intellectual capital on enterprise. The data, obtained from the calculations, is evaluated within the scope of FFP and the study was finalized.
\end{abstract}

KEYWORDS

Intellectual Capital, Sports Clubs, Financial Fair Play

\begin{tabular}{|c|c|c|}
\hline & $\begin{array}{c}\text { Makale Geliş Tarihi / Submission Date } \\
\text { 16.07.2020 }\end{array}$ & $\begin{array}{l}\text { Makale Kabul Tarihi / Date of Acceptance } \\
25.10 .2020\end{array}$ \\
\hline Atıf & \multicolumn{2}{|c|}{$\begin{array}{l}\text { Alagöz, A. ve Güler, Y. (2020). Düzenleyici Kurumların Türk Spor Kulüplerinde Entelektüel Sermaye Oluşumuna } \\
\text { Etkileri ve Bir Araştırma. Selçuk Üniversitesi Sosyal Bilimler Meslek Yüksekokulu Dergisi, } 23 \text { (2), 637-653. }\end{array}$} \\
\hline
\end{tabular}

\footnotetext{
* Prof. Dr., Selçuk Üniversitesi, İktisadi ve İdari Bilimler Fakültesi, İşletme Bölümü, aalagoz@ selcuk.edu.tr, ORCID: 0000-0002-7538-2213

** Yüksek Lisans Öğrencisi, Selçuk Üniversitesi, Sosyal Bilimler Enstitüsü, Muhasebe Bölümü, yasinguler@ windowslive.com, ORCID: 0000-00031766-3313
} 


\section{GİRIŞ}

Bilgi toplumuna geçiş, ekonominin yapısında ve makro / mikro anlamda kaynaklara karşı tutumda önemli değişiklikler olmasını sağlamıştır. Bilginin en önemli kaynak ve sermaye olduğunu temel alan bilgi ekonomisi yaklaşımında; fiziksel sermayenin korunması ve geliştirilmesine odaklanan bakış açısı yerini, en az fiziksel varlıklara önem verdiği kadar, belki de daha fazla, bilgi, beceri, iletişim vb. gibi maddi olmayan varlıklara önem veren bakış açısına bırakmıştır.

Bilgi toplumuna doğru yaşanan dönüşümle beraber ise; bilgi, yetenek, eğitim, iletişim vb. gibi sahip olana rekabet üstünlüğü sağlayan maddi olmayan unsurları içeren Entelektüel Sermaye kavramı ön plana çıkmıştır. Entelektüel sermaye kavramı, özellikle 90'lardan sonra yani; bilgi ve iletişim (bilişim) de yaşanan ve giderek hızlanan gelişmelerle beraber ortaya atılmış ve maddi olmayan unsurların işletmenin değerinin oluşmasında, maddi unsurlardan daha fazla etkisi olduğu vurgulanmıştır.

Spor, kişinin özgür isteklerine bağlı olarak değişen, bir değer ölçütleri içeren, kendisine özel teorileri olan, müsabakanın yanında şölen içinde yapılan, belli kurallar etrafında geliştirilen özgünleştirilen, yetkinleşmeyi öngören beden egzersizleri olarak değerlendirilmektedir. Spor faaliyetleri içinde futbol, şüphesiz insanların en çok ilgilendiği, faal ya da pasif olarak kişilerin spora en çok katılımını sağlayan ve dünyanın her tarafındaki ekonomik kesimleri yaptırıma zorlayan bir spor dalıdır. 1866 yılında İngiltere'de ilk resmi müsabakanın oynanmasıyla başlayan futbol her geçen popülaritesini artırmış, içinde tekstil, bahis, turizm, ulaşım ve medya gibi birçok sektörü içinde barındıran bir endüstri haline gelmiştir.

Futbol endüstrisinin bileşenlerini meydana getiren kişi, kurum ve organizasyonlar farkl1 endüstrilerde çalışan diğer firmalar gibi piyasanın kurallarına bağlıdırlar. Bu kurallardan dolayı kulüpler veri koşullar altında kârlarını veya faydalarını maksimize etmeye çalışırlar. Milyonlarca dolara ulaşan kulüp bütçeleri, sahip olunan tesisler, artan kamuoyu ilgisi, spor ekonomisinin gelişmesi ve korunmasını amaçlayan FIFA, UEFA, ülke federasyonlarının getirdiği düzenlemeler ve farklı boyutlarda yaşanan şiddetli rekabetin varlığı spor kulüplerinin dernek statüsünde yönetilmelerini imkansız hale getirirken modern yönetim anlayışına sahip kurumsallaşan ve güçlü bir finansal yapıya sahip olmayı kaçınılmaz bir şart olarak ortaya çıkarmıştır. Bu da futbol kulüplerinde idari, mali, teknik ve sportif açıdan farklı uzmanlık alanlarına sahip profesyonellerin görev almasına, profesyonel yöneticilerin sevk ve idaresinde şirketlerin doğmasina neden olmuştur.

Futbol ekonomisinin en önemli aktörlerinden futbol kulüplerinin son y1llarda göstermiş olduğu kötü mali performanslar, futbol ekonomisinin tüm bileşenlerini tehdit etmeye başlamıştır. Futbol kulüplerinin harcamalarını gelirlerinin çok üstünde yapması maaş ve borç yüklerinin artmasına, artan borç yükü karlarının ciddi oranda azalmasına yol açmıştır. Gelirlerinin büyük kısmını finansal giderlerine harcayan birçok futbol kulübünün ortaya çıkması mali disiplinden açık bir şekilde uzaklaşıldığının göstergesi haline gelmiştir

Avrupa Futbolu'nun en büyük düzenleyici ve denetleyici kurumu olan UEFA (the Union of European Football Associations), 2004-2005 sezonundan sonra geçerli olmak üzere ilk başta kulüp lisanslama kriterlerini getirmiştir. Bu uygulama ile tesisleşme, yönetim ve hukuki konularda ciddi başarılar yakalayan UEFA, mali kriterlerin yanına "Finansal Fair Play (FFP)" olarak adlandırdığı birçok kriter eklemiştir. FFP kriterleri ile temelde gelir-gider denkliğini sağlama amacı güden UEFA, futbol kulüplerinin mali yapılarını güçlendirmek adına birçok kurallar getirmiştir.

Her işletmede olduğu gibi spor kulüpleri de entelektüel sermayeye ve entelektüel sermayenin bileşenleri olan insan sermayesi, müşteri sermayesi ve ilişki sermayesine sahip birer işletme konumundadır. UEFA'nın FFP kapsamında getirdiği mali disiplinin sağlanmasına ilişkin kurallar futbol kulüplerinin de entelektüel sermaye değerlerini etkilemiştir.

Bu bağlamda çalışmamızda spor kulüplerinde düzenleyici kurumların entelektüel sermaye oluşumu üzerine etkileri incelenmiş ve Finansal Fair Play'in Türk Spor Kulüplerinde entelektüel sermaye üzerine etkisi incelenmiştir.

\section{LITERATÜR}

Entelektüel sermaye kavramı ile ilgili genel olarak kabul edilmiş net bir tanım bulunmamaktadır. En genel tanımıyla entelektüel sermaye, değer yaratmak amaciyla kullanılabilen (Hunter, 2005: 5), işletmenin kullanımına hazır olan, o işletmeye göreceli avantaj sağlayan ve bir bütün olarak gelecekte fayda sağlaması beklenen (Stam and Andriessen, 2004: 6), varlıkların görünmez değerler niteliği taşıdığ1; teknoloji, müşteri güveni, markalar gibi (Itami ve Roehl, 1991:9) işletmelerin mali tablolarında gösterilen maddi varlıklar ve finansal varlıkların dışında sahip oldukları (Koole and Roos, 2010: 349) değerlerdir.

Entelektüel sermayenin kavramsal olarak ele alınması, ölçülmesi, ölçüm yöntemlerinin değerlendirilmesi, farklı sektörlerle ilişkilendirilmesi ve muhasebeleştirilmesi ile ilgili literatürde yapılmış birçok çalışma 
bulunmaktadır. Çalışmamızın amacı ve kapsamı doğrultusunda literatürde yer alan çalışmalara aşağıda verilmiştir.

Shareef ve Davey (2005), spor kulüplerinin entelektüel sermayeye yer verip vermediğine ilişkin 19 İngiliz İngiliz futbol kulübünün 2002 dönemi yıllık raporlarını incelemiş, araştırma bulgularında, entelektüel sermaye bileşenlerinin listelenen profesyonel futbol kulüpleri tarafından zayıf bir şekilde rapor edildiğini tespit etmiş ve şirketlerin entelektüel sermaye bilgisini paydaşlara anlamlı bir şekilde sunmalarına yardımcı olmak için, futbol endüstrisine özel FRS rehberi geliştirilebileceği önerisini sunmuştur.

Eduardo vd., (2013), dünyanın en büyük 60 futbol kulübünün teknik direktörleri üzerinde kişisel refah ve entelektüel sermaye ilişkisini incelemiş, başarılı teknik direktörlerin hem kulübün hem de bireysel entelektüel değerlerini artırdığını, sürekli artan entelektüel değerlerin ise servetlerini artırarak refah seviyelerini yukarı taşıdığı sonucuna ulaşmıştır.

Gürel vd., (2013), entelektüel sermayenin temel bileşenlerinden fikri sermayeyi VAIC yöntemiyle BIST'de yer alan Beşiktaş, Fenerbahçe, Galatasaray ve Trabzonspor kulüplerinin üzerinde ölçmüştür. Çalışmanın sonucunda, entelektüel sermayeyi en verimli kullanan kulübün Galatasaray olduğunu ve kulüplerin daha yüksek entelektüel sermayeye ulaşmak içim futbol kulüpleri için daha yüksek pazar payına sahip olmaları gerektiğini savunmuşlardır.

Horasan (2013), ortaya koyduğu çalışmada entelektüel sermayenin bir bileşeni olan sporcu değerlerinin mali tablolara yansitılmasıyla ilgili model önerisi sunmuştur.

Ricci vd., (2015), çalışmalarında entelektüel sermayenin verimliliğinin (ICE) firma performansı üzerindeki etkisini ölçmüştür. İtalya Birinci Futbol Ligi (Serie A)'da, 2007/2008 ile 2011/2012 sezonları arasında yer alan futbol kulüplerinin üzerinde yaptıkları çalışmada, firma performansı üzerinde özellikle insan sermayesi verimliliğindeki artışın etkili olduğu sonucuna ulaşılmıştır.

Yaşar vd., (2015), çalışmalarında BIST'de yer alan Beşiktaş, Fenerbahçe, Galatasaray ve Trabzonspor kulüplerinin entelektüel sermaye verimliliğini $\mathrm{VAIC}^{\mathrm{TM}}$ yöntemiyle ölçmüş, futbol kulüplerinin ana unsurları maddi olmayan varlıklar olduğu için yöntemin spor kulüplerinin entelektüel sermayeyi ölçmelerinde etkili olduğunu ve entelektüel sermayenin yatırımcı kararlarını etkilediğini tespit etmişlerdir.

Panagiotis ve Evengelos (2015), yaptıkları çalışmada 9 Avrupa ülkesinden seçtiği birer kulübün 2005 ve 2010 yılları arasındaki entelektüel sermaye ve karlılık ilişkisini incelememiştir. Sonuç olarak entelektüel sermaye ve kârlılık arasında pozitif bir ilişki olduğunu, insan sermayesinin spesifik olarak entelektüel sermaye değerinde en önemli gösterge olduğunu, çalışanlara (oyuncular, teknik personel, vb.) daha fazla harcayan kulüplerin daha yüksek bir finansal performans katma değeri sağladığını öne sürmüşlerdir.

Igor (2016), çalışmasında Avrupa'da yer alan 10 kulübün 2011 ve 2015 yılları arasında entelektüel sermaye değerlerini Piyasa Değeri / Defter yöntemiyle ölçmüş, çalışmanın sonucunda yöntemin sadece borsada teşkilatlanmış kulüplerin üzerinde ölçüm yapılabildiği için yetersiz kaldığını fakat yöntem üzerinde değerlendirme yapıldığında entelektüel sermayeyi, insan sermayesi (futbolcular) ve müşteri sermayesinin en çok etkilediğini ortaya koymuştur.

Lardo vd., (2016), profesyonel futbol kulüplerinin, kullandığı sosyal medyanın organlarının entelektüel sermayeye etkisi üzerine çalışma yapmıştır. Çalı̧̧manın sonucunda sosyal medyadan kulüplerin ciddi miktarlarda gelir elde ettiği ve entelektüel sermaye değerlerini artırdığına ulaşılmıştır.

Leito ve Baptista (2019), çalışmalarında 1992 ve 2010 yılları arasında İngiliz Premier Ligi'ne katılan 35 İngiliz futbol kulübü üzerinde marka değeri ile entelektüel sermaye arasındaki ilişkiyi incelemiştir. Sonuç olarak, futbol kulüplerinin entelektüel sermayeyi, uygun bir şekilde yönettiklerinde, katma değer yaratan önemli bir varlık seti olduğunu ortaya koymuşlardır. Ligde ulaşılan başarının insan sermayesi verimliliği ve karı artırarak marka değeri üzerinde olumlu etki yarattığını belirtmişlerdir.

\section{METODOLOJI}

İşletmelerin doğrudan bilançolarına yansımayan fakat var olduğu da bir gerçek olan soyut varlıklarının ölçülmesi entelektüel sermaye ile mümkün olmaktadır (Canibano vd., 2004: 10). Birçok farklı yaklaşım ile işletmelerin sahip olduğu entelektüel sermayenin değeri ölçülmeye çalışılmıştır. Bunlardan bazıları bu değeri tutar olarak bazıları ise oran olarak bulmaktadır ve her yaklaşımın ihtiyaç duyduğu kalemler de farklıdır. Entelektüel sermayenin ölçülmesi için ortaya atılan yöntemlerin tutar ve oran olarak hesaplananları entelektüel sermayeyi işletme bazında ölçen yöntemler olarak incelenmektedir.

Entelektüel sermayeyi işletme bazında ölçen yöntemler, unsur bazında ölçen yöntemlere göre daha çok parasal nitelikte sonuçlar vermektedir. Entelektüel sermaye konusunda daha önce yapılmış birçok çalışma mevcuttur. Yapılan çalışmalar sektör bazlı incelendiğinde hizmet sektörün ağırlıkta olup, banka ve otel işletmeleri üzerine yapılan uygulamalar ön plana çıkmaktadır. Üretim işletmelerinde ise otomotiv sektörü baz 
alınarak daha çok uygulama yapılmıştır. Entelektüel sermayeyi işletme bazında ölçen yöntemlerin hepsinin uygulandığ çalışmalara literatürde az rastlanmaktır. Tek bir yöntem uygulandığında ise "Hesaplanmış Maddi Olmayan Değerler Yöntemi” kullanılmıştır. Çalışmaların büyük bölümünde bir yıllık verilerden yararlanılmıştır. Entelektüel sermayeyi unsur bazında ölçen yöntemlerde ise VAIC yöntemi uygulamaların büyük çoğunluğunu oluşturmaktadır. Entelektüel sermaye üzerinde yapılan diğer çalışmalarda ise entelektüel sermayenin muhasebeleştirilmesi, raporlanması ve örgüt performansına etkisi ele alınmıştır.

\subsection{Araştırmanın Amacı}

Çalışmanın amacı öncelikle hisseleri Borsa İstanbul (BIST)'de işlem gören Beşiktaş, Trabzonspor, Galatasaray ve Fenerbahçe spor kulüplerinin entelektüel sermayelerini ölçmek daha sonra kulüplerin mali tablolarını denetleyici kurumlardan biri olan UEFA'nın ortaya koyduğu Finansal Fair Play kriterlerin, entelektüel sermaye değişimine etkisini tespit etmektir.

Daha önce yapılmış uygulamalar sıklıkla farklı sektörlere ve BIST’te teşkilatlanmış farklı pazarlar üzerinde uygulanmış ve veriler bu yöntemlerden yalnız birisi ile değerlendirilmiştir. Yapılan literatür araştırmasında aynı örnekleme birden fazla ölçüm yönteminin uygulanmış olduğu bir çalışmaya çok az rastlanmıştır. Bu çalışma, uygulamaya konu olan sektörlerin bağlı oldukları düzenleyici ve denetleyici kurumların, işletmelerin entelektüel sermayelerine etkisini ölçen 10 yıllık veriler kullanılarak yapılmış ilk çalışmadır.

\subsection{Araştırmanın Kapsamı}

Araştırmanın kapsamına payları BIST'de işlem gören Beşiktaş, Trabzonspor, Galatasaray ve Fenerbahçe kulüplerinin karşılaştırma yapılması açısından, Finansal Fair Play kurallarının uygulanmaya başladığı sezon olan, 2013-2014 sezonundan çalışmamızın sonlandırıldığı döneme kadar olana 5 yıllık ve 2013-2014 sezonundan önceki 5 yıllık finansal bilgileri dahil edilmiştir. Futbol kulüplerinin BIST’te ifade edilen kodları ve isimlerinin bulunduğu liste, Tablo 1'de sunulduğu gibidir.

Tablo 1. BIST’te İşlem Gören Futbol Kulüpleri

\begin{tabular}{cccc}
\hline İşletme Kodu & İşletme Adı & Ödenmiş Sermaye (TL) & $\begin{array}{c}\text { Halka Açıklık } \\
\text { Oranı }\end{array}$ \\
\hline GSRAY & Galatasaray Sportif Sınai ve Ticari & 540.000 .000 & $\% 33,58$ \\
& Yatırımlar A.Ş. & $\% 32,93$ \\
\hline FENER & Fenerbahçe Futbol A.Ş. & 98.800 .000 & $\% 48,99$ \\
\hline BJKAS & Beşiktaş Futbol Yatırımları Sanayi ve & 240.000 .000 & $\% 35,25$ \\
& Ticaret A.Ş. & \\
\hline TSPOR & $\begin{array}{c}\text { Trabzonspor Sportif Yatırım ve Futbol } \\
\text { İşletmeciliği Ticaret A.Ş. }\end{array}$ & 236.390 .631 &
\end{tabular}

\subsection{Araştırmanın Yöntemi}

Entelektüel sermayeyi işletmenin tamamında ölçen yöntemler uygulamada daha sık kullanılmaktadır. Ancak bu yöntemlerden sayısal olarak ölçen yöntemlerin uygulanabilirlik dereceleri birbirinden farklı olmaktadır. Söz konusu yöntemlere örnek olarak, Piyasa Değeri/Defter Değeri, Tobin Q Oranı, Ekonomik Katma Değer, Entelektüel Katma Değer Katsayısı, Hesaplanmış Maddi Olmayan Varlık yöntemleri sayılabilir (Özevren ve Yıldız, 2010: 280-281). Çalışmamızda entelektüel sermayeyi işletme bazında ölçen yöntemler kullanılmıştır. İşletmelerin tek başına piyasa değerleri göz önüne alınmadan aynı zamanda sadece mali tablo bilgilerinden yararlanarak entelektüel sermaye değerine ulaşan söz konusu yöntemin uygulanabilmesi için, işletmelerin mali tablolarına ihtiyaç duyulmuştur.

Futbol kulüpleri, Sermaye Piyasası Kurulu'nun (SPK) 13 Haziran 2013 tarih ve 28676 sayılı Resmî Gazete'de yayımlanan Seri II, 14.1 No'lu “Sermaye Piyasasında Finansal Raporlamaya İlişkin Esaslar Tebliği hükümleri uyarınca Kamu Gözetimi Muhasebe ve Denetim Standartları Kurumu (KGK) tarafından yürürlüğe konulmuş olan Türkiye Muhasebe Standartları ve Türkiye Finansal Raporlama Standartları mevzuatına göre dönemsel olarak finansal raporlama yapmak zorundadırlar. Hazırladıkları finansal raporlar, bağımsız denetime tabi olup 3 ay, 6 ay, 9 ay ve yıllık mali tablolarını 'finansal raporlar"' başlığı altında KAP (Kamuoyu Aydınlatma Platformu)'nda yayınlamak zorundadırlar. Futbol kulüplerinin mali tablolarına ilişkin bilgiler KAP'nun resmi internet sitesinden elde edilmiştir. 


\subsection{Araştırmanın Bulguları}

Çalışmada entelektüel sermayeyi işletme bazında ölçen yöntemlerden, Piyasa Değeri/Defter Değeri, Tobin Q Oran1, Ekonomik Katma Değer, Entelektüel Katma Değer Katsayısı, Hesaplanmış Maddi Olmayan Varlık yöntemlerinin her biri ayrı ayrı Beşiktaş, Trabzonspor, Galatasaray ve Fenerbahçe kulüplerine uygulanmıştır. Fakat çalışmamızı, kısa ve öz tutmak amacıyla, her yöntemin uygulanma adımı veya adımları tek bir kulüp için verilecektir.

\subsubsection{Piyasa Değeri/Defter Değeri Oranı Yöntemi Aracılığıyla Entelektüel Sermaye Ölçümü}

Piyasa değeri/defter değeri oranı, bir şirketin şirket hisse senetlerinin borsada oluşan piyasa değerinin ilgili şirketin defter değerine bölünmesi ile hesaplanmaktadır. Defter değeri ise, toplam varlıkların toplam yükümlülüklerden farkını göstermektedir. Yöntem, aşağıdaki şekilde formüle edilmektedir (Çetin, 2005: 364).

$$
\frac{\text { piyasa değeri }}{\text { defter değeri }}=\frac{\text { Hisse Senedi Birim Fiyatı x Dolașımdaki Hisse Senedi Sayısıeğeri }}{\text { Toplam Varlıklar-Toplam Yükümlülükler }}
$$

Beşiktaş Spor Kulübü'nün piyasa değeri/defter değeri yöntemine göre son 10 y1llık entelektüel sermaye değerleri aşağıdaki Tablo 2'de verilmiştir.

Tablo 2. Beşiktaş Spor Kulübü PD/DD Değeri

\begin{tabular}{|c|c|c|c|c|c|c|}
\hline & $\begin{array}{c}\text { Hisse Senedi } \\
\text { Fiyatı (‡) }\end{array}$ & $\begin{array}{c}\text { Hisse Senedi } \\
\text { Adedi }\end{array}$ & $\begin{array}{c}\text { Piyasa Değeri } \\
(\mathbf{(})\end{array}$ & $\begin{array}{c}\text { Defter Değeri } \\
(\mathbf{(})\end{array}$ & PD-DD & PD/DD \\
\hline 2009 & 1,44 & 40.000 .000 & 57.600 .000 & $(15.387 .483)$ & 42.212 .517 & $-3,74$ \\
\hline 2010 & 1,41 & 40.000 .000 & 56.400 .000 & $(63.781 .109)$ & -7.381 .109 & $-0,88$ \\
\hline 2011 & 3,29 & 40.000 .000 & 131.600 .000 & $(201.324 .028)$ & -69.724 .028 & $-0,65$ \\
\hline 2012 & 1,56 & 40.000 .000 & 62.400 .000 & $(352.120 .198)$ & -262.720 .198 & $-0,178$ \\
\hline 2013 & 1,54 & 240.000 .000 & 369.600 .000 & $(219.774 .261)$ & 149.825 .639 & $-1,681$ \\
\hline 2014 & 2,02 & 240.000 .000 & 484.800 .000 & $(364.056 .139)$ & 120.743 .861 & $-1,331$ \\
\hline 2015 & 1,91 & 240.000 .000 & 458.400 .000 & $(487.578 .194)$ & -29.178 .194 & $-0,94$ \\
\hline 2016 & 3,21 & 240.000 .000 & 770.400 .000 & $(546.370 .532)$ & 224.029 .468 & $-1,41$ \\
\hline 2017 & 4,53 & 240.000 .000 & 1.187 .200 .000 & $(518.808 .617)$ & 668.391 .383 & $-2,288$ \\
\hline 2018 & 2,25 & 240.000 .000 & 540.000 .000 & $(509.028 .697)$ & 30.971 .303 & $-1,060$ \\
\hline
\end{tabular}

Tablo 3. Spor Kulüplerinin 2009-2018 Yılları PD/DD Yöntemine Göre Entelektüel Sermaye Tutarı ve Değeri

\begin{tabular}{ccccccccc}
\hline & \multicolumn{2}{c}{ Beşiktaș } & \multicolumn{2}{c}{ Fenerbahçe } & \multicolumn{2}{c}{ Galatasaray } & \multicolumn{2}{c}{ Trabzonspor } \\
\hline & PD-DD & PD/DD & PD-DD & PD/D & PD-DD & PD/D & PD-DD & PD/D \\
\hline $\mathbf{2 0 0 9}$ & 42.212 .517 & $-3,74$ & 517.499 .725 & 23,74 & -110.582 .710 & $-0,06$ & 32.934 .699 & $-1,92$ \\
\hline $\mathbf{2 0 1 0}$ & -7.381 .109 & $-0,88$ & 496.334 .171 & 18,94 & -123.290 .132 & $-0,06$ & 19.023 .636 & $-1,39$ \\
\hline $\mathbf{2 0 1 1}$ & -69.724 .028 & $-0,65$ & 590.590 .154 & 4,51 & -188.641 .385 & $-0,12$ & 63.158 .313 & 2,04 \\
\hline $\mathbf{2 0 1 2}$ & -262.720 .198 & $-0,178$ & 391.960 .720 & 4,36 & -240.418 .699 & $-0,04$ & 19.899 .587 & 1,29 \\
\hline $\mathbf{2 0 1 3}$ & 149.825 .639 & $-1,681$ & 295.499 .622 & 3,40 & -34.433 .592 & $-0,51$ & 34.501 .064 & $-2,92$ \\
\hline $\mathbf{2 0 1 4}$ & 120.743 .861 & $-1,331$ & 149.468 .034 & $-1,62$ & 22.128 .764 & $-2,45$ & -34.846 .130 & $-0,53$ \\
\hline $\mathbf{2 0 1 5}$ & -29.178 .194 & $-0,94$ & -35.298 .704 & $-0,92$ & -60.710 .221 & $-0,42$ & 68.754 .022 & $-2,22$ \\
\hline $\mathbf{2 0 1 6}$ & 224.029 .468 & $-1,41$ & 73.975 .139 & $-1,18$ & -331.814 .987 & $-0,09$ & 94.330 .806 & $-1,55$ \\
\hline $\mathbf{2 0 1 7}$ & 668.391 .383 & $-2,288$ & -52.841 .998 & $-0,85$ & -554.826 .949 & $-0,08$ & -41.108 .927 & $-0,85$ \\
\hline $\mathbf{2 0 1 8}$ & 30.971 .303 & $-1,060$ & -293.058 .522 & $-0,65$ & 710.365 .670 & $-3,25$ & -458.883 .520 & $-0,21$ \\
\hline
\end{tabular}

Spor kulüplerinin entelektüel sermayeyi ölçme yöntemlerinden Piyasa Değeri ve Defter Değeri metoduna göre 2009 ve 2018 yılları arasında gerçekleşen entelektüel sermaye oranları ve tutarları Tablo 3'te birleştirilerek rakamsal olarak verilmiştir.

Her yıl için 31.05.2009 tarihindeki hisse senedi fiyatı, bu tarihteki hisse senedi adedi çarpılarak işletmenin piyasa değeri elde edilmiştir. Defter değeri her yıl dönem sonu bilançosundan alınmıştır. Hesaplanmış piyasa değerinden defter değerinin çıkarılması ile elde edilen fark bu işletmenin hesaplanan yılın sonundaki ES tutarını ifade etmektedir. Ayrıca ES tutarıyla, bu tutarın işletmenin defter değerine oranı ile elde edilmiş PD/DD, ES oranı olarak ifade edilmektedir. Hesaplamaya ilişkin veriler Tablo 3'te verilmiştir. 
PD/DD 1'den büyük olması işletmeye söz konusu yıl içinde piyasa oyuncuları tarafından özkaynaklarından daha fazla değer biçildiği anlamına gelir. Bu durumda işletmenin ES'si "var" kabul edilir. Oranın 1'den düşük olması işletmenin kaynaklarını verimli kullanmadığını gösterir. Bu durumda PD-DD tutarı negatif olacaktır ve bu da ES'si “yok" şeklinde de yorumlanabilecektir.

\subsubsection{Tobin'in Q Oranı Yöntemi Aracılı̆̆ıyla Entelektüel Sermaye Ölçümü}

Tobin tarafından 1969 yılında ortaya çıkarılan ve Tobin q oranı yöntemi adıyla anılan bu yöntem, işletmenin piyasa değerinin varlıkları yerine koyma maliyetine oranlanmasıyla hesaplanmaktadır. Yapılan çalışmalarda Tobin q oranı pek çok amaçla kullanılmıştır. Çoğunlukla sahiplik yapısı ile performans arasındaki ilişkiyi ölçmek amacıyla kullanılmasına rağmen, kâr dağıtım kararlarının hisse senedi değeri üzerine etkisinin ölçülmesi, firma sahipliği ile özsermaye değeri arasındaki ilişkinin belirlenmesi, yönetimsel performansın ölçülmesi gibi konularda da bu orandan yararlanılmıştır. Tobin'in Q Oranı Yöntemi aşağıdaki şekilde formüle edilir (Ross ve Ross, 1997: 4-5);

$$
q=\frac{\text { Toplam Piyasa Değeri }}{\text { Şirket Varlıklarınının Yerine Koyma Maliyeti }}(2)
$$

Tobin q oranının belirlenmesinde en önemli güçlük yerine varlıkların koyma maliyetinin hesaplanmasıdır. Bu nedenle, konuyla ilgili literatürde yerine koyma maliyetlerinin farklı yöntemlerle hesaplanması önemli bir yer tutmaktadır. Varlıkların pazar değerinin hesaplanması konusunda uzlaşı sağlanmış görünmektedir. Bu nedenle çalışmanın uygulama bölümünde de kullanılan Yaklaşık Tobin Q Oranı, Chung ve Pruitt tarafından 1994 yılında geliştirilen aşağıdaki formül kullanılacaktır (Chung ve Pruitt, 1994: 71).

$$
\begin{aligned}
& \text { Yaklaşık Tobin Q Değeri }=\lfloor P D+(T B-D V)\rfloor-A T \\
& \text { Yaklaşık Tobin Q Oranı }=\lfloor P D+(T B-D V)\rfloor / A T \\
& P D=\text { Ödenmiş Sermaye } * \text { Ortalama Hisse Fiyatı }
\end{aligned}
$$

\section{PD: Piyasa Değeri}

AT: Aktif Toplamı

TB: Toplam Borçlar

\section{DV: Dönen Varıklar Toplamı}

\begin{tabular}{|c|c|c|c|c|c|c|}
\hline & $\begin{array}{c}\text { Piyasa } \\
\text { Değeri (‡) }\end{array}$ & $\begin{array}{c}\text { Toplam } \\
\text { Borçlar (\$) }\end{array}$ & $\begin{array}{c}\text { Dönen } \\
\text { Varlık (†) }\end{array}$ & $\begin{array}{c}\text { Aktif } \\
\text { Toplam (f) }\end{array}$ & $\begin{array}{c}\text { Tobin Q } \\
\text { Değeri (ł) }\end{array}$ & $\begin{array}{c}\text { Tobin Q } \\
\text { Oranı }\end{array}$ \\
\hline 2009 & 540.250 .000 & 77.520 .275 & 34.126 .750 & 54.770 .000 & 528.873 .525 & 10,56 \\
\hline 2010 & 524.000 .000 & 69.663 .298 & 36.125 .450 & 41.997 .469 & 515.540 .379 & 13,27 \\
\hline 2011 & 758.500 .000 & 23.295 .520 & 154.037 .506 & 191.205 .366 & 436.552 .648 & 3,28 \\
\hline 2012 & 508.500 .000 & 244.200 .359 & 114.656 .495 & 360.739 .639 & 277.304 .225 & 1,76 \\
\hline 2013 & 418.500 .000 & 424.852 .689 & 266.382 .840 & 547.853 .067 & 29.116 .782 & 1,05 \\
\hline 2014 & 390.000 .000 & 586.343 .490 & 68.277 .073 & 345.811 .524 & 562.254 .893 & 2,62 \\
\hline 2015 & 387.000 .000 & 733.531 .883 & 95.593 .332 & 311.233 .179 & 741.021 .631 & 3,38 \\
\hline 2016 & 477.366 .400 & 955.145 .813 & 288.066 .592 & 551.214 .551 & 593.231 .070 & 2,07 \\
\hline 2017 & 479.346 .000 & 1.223 .042 .847 & 447.979 .758 & 660.854 .849 & 593.554 .240 & 1,89 \\
\hline 2018 & 546.652 .400 & 2.039 .133 .083 & 1.084 .908 .444 & 1.199 .422 .161 & 301.454 .878 & 1,25 \\
\hline
\end{tabular}

Yukarıda verilen Tobin Q Oranı formülüne göre Fenerbahçe Spor Kulübü’ne ilişkin entelektüel sermaye değerleri aşağıdaki Tablo 4'te verilmiştir.

Tablo 4. Fenerbahçe Spor Kulübü Tobin Q Oranı Yöntemi ile Entelektüel Sermaye Değeri

Tablo 5. Spor Kulüplerinin 2009-2018 Yılları Tobin Q Yöntemine Göre Entelektüel Sermaye Tutarı ve Değeri

\begin{tabular}{ccccccccc}
\hline & \multicolumn{2}{c}{ Beşiktaş } & \multicolumn{2}{c}{ Fenerbahçe } & \multicolumn{2}{c}{ Galatasaray } & \multicolumn{2}{c}{ Trabzonspor } \\
\hline & Q Değeri & $\begin{array}{c}\text { Q } \\
\text { Oranı }\end{array}$ & Q Değeri & $\begin{array}{c}\text { Q } \\
\text { Oranı }\end{array}$ & Q Değeri & $\begin{array}{c}\text { Q } \\
\text { Oranı }\end{array}$ & Q Değeri & $\begin{array}{c}\text { Q } \\
\text { Oranı }\end{array}$ \\
\hline $\mathbf{2 0 0 9}$ & -1.608 .724 & 0,99 & 528.873 .525 & 10,56 & 62.672 .954 & 1,61 & 77.502 .430 & 2,15 \\
\hline $\mathbf{2 0 1 0}$ & 23.266 .430 & 1,10 & 515.540 .379 & 13,27 & 68.167 .854 & 1,58 & 63.029 .629 & 1,75 \\
\hline
\end{tabular}




\begin{tabular}{ccccccccc}
\hline $\mathbf{2 0 1 1}$ & 282.167 .993 & 2,83 & 436.552 .648 & 3,28 & 160.647 .018 & 2,13 & -29.496 .546 & 0,81 \\
\hline $\mathbf{2 0 1 2}$ & 382.721 .976 & 4,01 & 277.304 .225 & 1,76 & 205.853 .211 & 1.35 & -8.886 .681 & 1,53 \\
\hline $\mathbf{2 0 1 3}$ & 557.293 .312 & 6,53 & 29.116 .782 & 1,05 & 5.384 .865 & 1 & 63.335 .718 & 1,34 \\
\hline $\mathbf{2 0 1 4}$ & 823.747 .307 & 8,88 & 562.254 .893 & 2,62 & -131.850 .341 & 0,8 & 97.441 .420 & 1,58 \\
\hline $\mathbf{2 0 1 5}$ & 875.816 .402 & 5,87 & 741.021 .631 & 3,38 & -156.048 .557 & 0,81 & 155.502 .646 & 1,57 \\
\hline $\mathbf{2 0 1 6}$ & 1.130 .307 .649 & 4,82 & 593.231 .070 & 2,07 & 202.137 .655 & 1,30 & 401.084 .873 & 2,80 \\
\hline $\mathbf{2 0 1 7}$ & 1.508 .471 .680 & 3,74 & 593.554 .240 & 1,89 & 315.391 .085 & 1,41 & 504.351 .320 & 2,46 \\
\hline $\mathbf{2 0 1 8}$ & 518.283 .906 & 1,54 & 301.454 .878 & 1,25 & 810.370 .728 & 1,81 & 640.180 .394 & 2,59
\end{tabular}

Tablo 5'te spor kulüplerinin 10 yıllık hesaplanmış q değerleri yer almaktadır. PD/DD oranına getirilen eleştiriler Tobin'in Q Oranı Yöntemi'nde de sözkonusudur. Yöntemde, hesaplanan Q oranının 1'in altında bulunması işletmenin entelektüel sermayesinin (ES) olmadığı anlamına gelmemeli, işletmenin piyasa değerinin mevsimsel dalgalanma kaynaklı düşüş göstermesi ya da kısa vadeli borçlarının yükselerek toplam aktifleri aşmasından da kaynaklandığı unutulmamalıdır (Bontis, 1998: 64). Spor kulüplerinin ES değerleri ve tutarları PD/DD yönteminde olduğu gibi artış veya azalış şeklinde trend göstermiştir. Oluşan bu trendlerin yönü aynı sebeplere bağlanabilir. Tobin q oranının 10 yıllık seyri incelendiğinde 2013 yılı sonrası kur değişimleri, etkisini q oranında da göstermektedir. Bu trend PD/DD trendine benzemektedir. Fakat 2013 yılından önceki q oranı yakalanmıştır. Q oranı neredeyse tüm yıllarda 1'in üstünde gerçekleşmiştir. Bu, spor kulüplerinin varlıklarını verimli şekilde kullandıklarını gösterir. Fakat PD/DD oranı düşünüldüğünde aynı ifadeyi kullanmak mümkün olmayacaktır. Q oranının trendi makul gözükse de q değerlerinin hesaplanması için, bu veri kümesi için, başka yöntemlerin kullanılması gerekir.

\subsubsection{Hesaplanmış Maddi Olmayan Değer Yöntemi Aracılığıyla Entelektüel Sermaye Ölçümü}

Hesaplanmış maddi olmayan değer yöntemi sürecinde 7 adım uygulanarak entelektüel sermaye değerine ulaş11ır (Stewart, 1997: 11)

1. Adım: İşletmenin hesaplanan yıl ve geçmiş iki yıl dahil, üç yıllık vergi öncesi karının ortalaması alınır.

Tablo 6. Spor Kulüplerinin Ụ̧̈ Yıllık Ortalama Vergiden Önceki Karlarının Hesaplanması

\begin{tabular}{|c|c|c|c|c|}
\hline & Beşiktaş & Fenerbahçe & Galatasaray & Trabzonspor \\
\hline \multirow[t]{4}{*}{2009} & 1.140 .527 & 4.250 .195 & 24.258 .430 & 2.130 .940 \\
\hline & $(1.259 .182)$ & 3.143 .323 & 70.396 .580 & 8.960 .930 \\
\hline & $(29.359 .333)$ & 3.143 .323 & 88.265 .870 & 8.960 .930 \\
\hline & (8.159.329) & 3.158.022 & 60.973 .626 & 6.684 .266 \\
\hline \multirow[t]{4}{*}{2010} & $(1.259 .182)$ & 3.143 .323 & 70.396 .580 & 2.130 .940 \\
\hline & $(29.359 .333)$ & 3.143 .323 & 88.265 .870 & 8.960 .930 \\
\hline & $(48.442 .389)$ & 17.290 .645 & 22.470 .780 & 58.291 .186 \\
\hline & $(26.356 .634)$ & 7.859 .097 & 60.377 .743 & 23.127.685 \\
\hline \multirow[t]{4}{*}{2011} & $(29.359 .333)$ & 3.143 .323 & 88.265 .870 & 8.960 .930 \\
\hline & $(48.442 .389)$ & 17.290 .645 & 22.470 .780 & 58.291 .186 \\
\hline & $(120.079 .175)$ & 96.881 .278 & $(67.659 .271)$ & 74.013 .197 \\
\hline & $(65.960 .295)$ & 39.105.082 & 14.359.126 & 47.121.771 \\
\hline \multirow[t]{4}{*}{2012} & $(48.442 .389)$ & 17.290 .645 & 22.470 .780 & 58.291 .186 \\
\hline & $(120.079 .175)$ & 96.881 .278 & $(67.659 .271)$ & 74.013 .197 \\
\hline & $(150.796 .170)$ & 5.958 .977 & $(36.015 .738)$ & 5.758 .726 \\
\hline & $(106.439 .234)$ & 40.043.633 & (27.068.076) & 46.021.036 \\
\hline \multirow[t]{4}{*}{2013} & $(120.079 .175)$ & 96.881 .278 & $(67.659 .271)$ & 74.013 .197 \\
\hline & $(150.796 .170)$ & 5.958 .977 & $(36.015 .738)$ & 5.758 .726 \\
\hline & $(66.266 .254)$ & 5.405 .295 & $(110.039 .892)$ & $(61.181 .611)$ \\
\hline & $(112.380 .533)$ & 36.082.850 & $(71.234 .970)$ & 6.196 .770 \\
\hline \multirow[t]{4}{*}{2014} & $(150.796 .170)$ & 5.958 .977 & $(36.015 .738)$ & 5.758 .726 \\
\hline & $(66.266 .254)$ & 5.405 .295 & $(110.039 .892)$ & $(61.181 .611)$ \\
\hline & $(143.175 .728)$ & $(121.818 .204)$ & $(113.946 .838)$ & $(50.972 .688)$ \\
\hline & $(120.079 .384)$ & $(36.817 .977)$ & $(86.667 .489)$ & (35.465.191) \\
\hline \multirow[t]{4}{*}{2015} & $(66.266 .254)$ & 5.405 .295 & $(110.039 .892)$ & $(61.181 .611)$ \\
\hline & $(143.175 .728)$ & $(121.818 .204)$ & $(113.946 .838)$ & $(50.972 .688)$ \\
\hline & $(130.597 .699)$ & $(181.718 .450$ & $(92.292 .817)$ & $(104.030 .351)$ \\
\hline & $(113.346 .560)$ & (99.377.119) & (106.413.182) & (72.061.550) \\
\hline
\end{tabular}




\begin{tabular}{|c|c|c|c|c|}
\hline \multirow[t]{4}{*}{2016} & $(143.175 .728)$ & (121.818.204) & $(113.946 .838)$ & $(50.972 .688)$ \\
\hline & $(130.597 .699)$ & $(181.718 .450)$ & $(92.292 .817)$ & $(104.030 .351)$ \\
\hline & $(57.827 .748)$ & (116.632.067) & $(75.961 .093)$ & (113.465.407) \\
\hline & $(110.533 .791)$ & $(140.056 .240)$ & (94.066.916) & $(89.489 .482)$ \\
\hline \multirow[t]{4}{*}{2017} & $(130.597 .699)$ & $(181.718 .450)$ & $(92.292 .817)$ & $(104.030 .351)$ \\
\hline & $(57.827 .748)$ & $(116.632 .067)$ & $(75.961 .093)$ & $(113.465 .407)$ \\
\hline & 7.229 .810 & (151.495.354) & $(280.899 .461)$ & $(112.198 .968)$ \\
\hline & $(60.398 .545)$ & (149.948.623) & (149.717.790) & $(109.898 .265)$ \\
\hline \multirow[t]{4}{*}{2018} & $(57.827 .748)$ & (116.632.067) & $(75.961 .093)$ & (113.465.407) \\
\hline & 7.229 .810 & (151.495.354) & (280.899.461) & (112.198.968) \\
\hline & 19.484 .121 & (275.439.294) & $(232.988 .552)$ & (292.463.607) \\
\hline & (10.371.279) & (181.188.905) & (196.616.385) & (172.709.327) \\
\hline
\end{tabular}

2. Adım: İşletmenin hesaplanan yıl ve geçmiş iki yıl dahil, üç yıllık maddi varlıklarının ortalaması alınır.

Tablo 7. Spor Kulüplerinin Üç Yıllık Ortalama Maddi Varlık Tutarlarının Hesaplanması

\begin{tabular}{|c|c|c|c|c|}
\hline & Beşiktaş & Fenerbahçe & Galatasaray & Trabzonspor \\
\hline \multirow[t]{4}{*}{2009} & 724.245 & 4.991 .202 & 253.977 & 1.177 .930 \\
\hline & 828.691 & 5.069 .425 & 300.992 & 3.254 .295 \\
\hline & 10.204 .253 & 6.004 .815 & 585.253 & 4.292 .526 \\
\hline & 3.919.053 & 5.355 .147 & 380.074 & 2.908.250 \\
\hline \multirow[t]{4}{*}{2010} & 828.691 & 5.069 .425 & 300.992 & 3.254 .295 \\
\hline & 10.204 .253 & 6.004 .815 & 585.253 & 4.292 .526 \\
\hline & 9.604 .303 & 8.585 .952 & 2.963 .712 & 4.520 .166 \\
\hline & 6.879.082 & 6.553.367 & 1.283.319 & 4.022.329 \\
\hline \multirow[t]{4}{*}{2011} & 10.204 .253 & 6.004 .815 & 585.253 & 4.292 .526 \\
\hline & 9.604 .303 & 8.585 .952 & 2.963 .712 & 4.520 .166 \\
\hline & 9.952 .370 & 2.170 .254 & 8.753 .618 & 4.118 .472 \\
\hline & 9.920.308 & 5.587 .007 & 4.100.861 & 4.310.388 \\
\hline \multirow[t]{4}{*}{2012} & 9.604 .303 & 8.585 .952 & 2.963 .712 & 4.520 .166 \\
\hline & 9.952 .370 & 2.170 .254 & 8.753 .618 & 4.118 .472 \\
\hline & 9.064 .158 & 9.231 .071 & 12.098 .758 & 6.540 .909 \\
\hline & 9.540.277 & 6.662 .425 & 7.938 .696 & 5.059 .849 \\
\hline \multirow[t]{4}{*}{2013} & 9.952 .370 & 2.170 .254 & 8.753 .618 & 4.118 .472 \\
\hline & 9.064 .158 & 9.231 .071 & 12.098 .758 & 6.540 .909 \\
\hline & 1.592 .266 & 9.261 .739 & 12.256 .432 & 7.132 .209 \\
\hline & 6.869 .598 & 6.887.688 & 11.036.269 & 5.930 .530 \\
\hline \multirow[t]{4}{*}{2014} & 9.064 .158 & 9.231 .071 & 12.098 .758 & 6.540 .909 \\
\hline & 1.592 .266 & 9.261 .739 & 12.256 .432 & 7.132 .209 \\
\hline & 2.430 .192 & 10.549 .063 & 7.833 .998 & 5.059 .241 \\
\hline & 4.362.205 & 9.680 .624 & 10.729 .729 & 6.244 .119 \\
\hline \multirow[t]{4}{*}{2015} & 1.592 .266 & 9.261 .739 & 12.256 .432 & 7.132 .209 \\
\hline & 2.430 .192 & 10.549 .063 & 7.833 .998 & 5.059 .241 \\
\hline & 2.486 .473 & 9.567 .661 & 9.345 .197 & 4.278 .066 \\
\hline & 2.169.643 & 9.792 .821 & 9.811 .875 & 5.489 .838 \\
\hline \multirow[t]{4}{*}{2016} & 2.430 .192 & 10.549 .063 & 7.833 .998 & 5.059 .241 \\
\hline & 2.486 .473 & 9.567 .661 & 9.345 .197 & 4.278 .066 \\
\hline & 9.144 .139 & 14.537 .301 & 9.960 .525 & 2.946 .000 \\
\hline & 4.686.934 & 11.551.341 & 9.046 .423 & 4.094.435 \\
\hline \multirow[t]{4}{*}{2017} & 2.486 .473 & 9.567 .661 & 9.345 .197 & 4.278 .066 \\
\hline & 9.144 .139 & 14.537 .301 & 9.960 .525 & 2.946 .000 \\
\hline & 260.888 .859 & 15.747 .090 & 10.349 .365 & 4.050 .032 \\
\hline & 90.839 .823 & 13.284.017 & 9.885 .029 & 3.758.032 \\
\hline \multirow[t]{4}{*}{2018} & 9.144 .139 & 14.537 .301 & 9.960 .525 & 2.946 .000 \\
\hline & 260.888 .859 & 15.747 .090 & 10.349 .365 & 4.050 .032 \\
\hline & 259.612 .463 & 20.838 .064 & 12.836 .652 & 3.230 .852 \\
\hline & 176.548.487 & 17.040 .818 & 11.048.717 & 3.408 .961 \\
\hline
\end{tabular}


3. Adım: Ortalama vergi öncesi kar, ortalama maddi varlıklara bölünerek maddi varlık getirisi bulunur. $\mathrm{Bu}$ durum aşağıdaki Tablo 8'de gösterilmiştir.

Tablo 8. Spor Kulüplerinin Ortalama Maddi Varlıklarının Getirisi

\begin{tabular}{|c|c|c|c|c|}
\hline & Beşiktaş & Fenerbahçe & Galatasaray & Trabzonspor \\
\hline \multirow[t]{3}{*}{2009} & $(8.159 .329)$ & 3.158 .022 & 60.973 .626 & 6.684 .266 \\
\hline & 3.919 .053 & 5.355 .147 & 380.074 & 2.908 .250 \\
\hline & $(\% 208)$ & $\% 60$ & $\% 1604$ & $\% 229$ \\
\hline \multirow[t]{3}{*}{2010} & $(26.356 .634)$ & 7.859 .097 & 60.377 .743 & 23.127 .685 \\
\hline & 6.879 .082 & 6.553 .367 & 1.283 .319 & 4.022 .329 \\
\hline & $(\% 383)$ & $\% 119$ & $\% 4704$ & $\% 574$ \\
\hline \multirow[t]{3}{*}{2011} & $(65.960 .295)$ & 39.105 .082 & 14.359 .126 & 47.121 .771 \\
\hline & 9.920 .308 & 5.587 .007 & 4.100 .861 & 4.310 .388 \\
\hline & $(\% 664)$ & $\% 700$ & $\% 350$ & $\% 1093$ \\
\hline \multirow[t]{3}{*}{2012} & $(106.439 .234)$ & 40.043 .633 & $(27.068 .076)$ & 46.021 .036 \\
\hline & 9.540 .277 & 6.662 .425 & 7.938 .696 & 5.059 .849 \\
\hline & $(\% 1110)$ & $\% 601$ & $(\% 340)$ & $\% 909$ \\
\hline \multirow[t]{3}{*}{2013} & $(112.380 .533)$ & 36.082 .850 & $(71.234 .970)$ & 6.196 .770 \\
\hline & 6.869 .598 & 6.887 .688 & 11.036 .269 & 5.930 .530 \\
\hline & $(\% 1630)$ & $\% 523$ & $(\% 646)$ & $\% 104$ \\
\hline \multirow[t]{3}{*}{2014} & $(120.079 .384)$ & $(36.817 .977)$ & $(86.667 .489)$ & $(35.465 .191)$ \\
\hline & 4.362 .205 & 9.680 .624 & 10.729 .729 & 6.244 .119 \\
\hline & $(\% 2752)$ & $(\% 380)$ & $(\% 807)$ & $(\% 567)$ \\
\hline \multirow[t]{3}{*}{2015} & $(113.346 .560)$ & (99.377.119) & $(106.413 .182)$ & $(72.061 .550)$ \\
\hline & 2.169 .643 & 9.792 .821 & 9.811 .875 & 5.489 .838 \\
\hline & $(\% 5221)$ & $(\% 1010)$ & (\%1084) & $(\% 1312)$ \\
\hline \multirow[t]{3}{*}{2016} & $(110.533 .791)$ & $(140.056 .240)$ & $(94.066 .916)$ & $(89.489 .482)$ \\
\hline & 4.686 .934 & 11.551 .341 & 9.046 .423 & 4.094 .435 \\
\hline & $(\% 2357)$ & $(\% 1210)$ & (\%1039) & $(\% 2185)$ \\
\hline \multirow[t]{3}{*}{2017} & $(60.398 .545)$ & $(149.948 .623)$ & $(149.717 .790)$ & $(109.898 .265)$ \\
\hline & 90.839 .823 & 13.284 .017 & 9.885 .029 & 3.758 .032 \\
\hline & $(\% 66)$ & $(\% 1128)$ & $(\% 1514)$ & $(\% 2924)$ \\
\hline \multirow[t]{3}{*}{2018} & $(10.371 .279)$ & $(181.188 .905)$ & $(196.616 .385)$ & $(172.709 .327)$ \\
\hline & 176.548 .487 & 17.040 .818 & 11.048 .717 & 3.408 .961 \\
\hline & $(\% 5)$ & $(\% 1063)$ & $(\% 1779)$ & $(\% 5066)$ \\
\hline
\end{tabular}

4. Adım: Sektörün hesaplanan yıl ve geçmiş iki yıl dahil, üç yıllık maddi varlıklarının ortalaması alınır. İşletmenin maddi varlık getirisi sektör ortalamasının altında ise hesaplamaya devam edilemez. Bu sebeple aşağıdaki Tablo 9'da sektörün maddi varlık karlılık oranları hesaplanmıştır.

Tablo 9. Sektörün Ortalama Maddi Varlık Karlılık Oranı

\begin{tabular}{cc}
\hline & Ortalama Maddi Varlık Karlılı Oranı \\
\hline $\mathbf{2 0 0 9}$ & $\% 421$ \\
\hline $\mathbf{2 0 1 0}$ & $\% 1253$ \\
\hline $\mathbf{2 0 1 1}$ & $\% 369$ \\
\hline $\mathbf{2 0 1 3}$ & $(\% 15)$ \\
\hline $\mathbf{2 0 1 4}$ & $(\% 412)$ \\
\hline $\mathbf{2 0 1 5}$ & $(\% 1126)$ \\
\hline $\mathbf{2 0 1 6}$ & $(\% 2156)$ \\
\hline $\mathbf{2 0 1 7}$ & $(\% 1697)$ \\
\hline $\mathbf{2 0 1 8}$ & $(\% 1408)$ \\
\hline
\end{tabular}

5. Adım: İşletmenin maddi varlık getirisi sektör ortalamasının üstünde ise getiri fazlası hesaplanır. Sektörün maddi varlıklar getirisi ile işletmenin maddi varlıklar getirisi çarpılarak normal kazanç bulunur. Normal kazanç, sektördeki ortalama bir işletmenin bu büyüklükteki maddi duran varlıklarından elde edeceği miktar anlamına gelmektedir. Ortalama vergi öncesi kardan normal kazanç çıkarılarak brüt kazanç elde edilir. 
Brüt kazanç, işletmenin ortalama bir işletmeden ne kadar fazla kâr ettiğini göstermektedir. Çalışmamızın 5. Adımına göre futbol kulüplerinin 2009 ve 2018 yılları arasındaki, hesaplamaya dahil edilebilen yıllar aşağıdaki Tablo 10'da verilmiştir.

Tablo 10. Spor Kulüplerinin Brüt Ek Kazanç Tutarlarının Hesaplanması

\begin{tabular}{|c|c|c|c|c|c|c|}
\hline & & $\begin{array}{c}\text { Maddi } \\
\text { Varlık } \\
\text { Ortalaması } \\
1\end{array}$ & $\begin{array}{c}\text { Sektörün } \\
\text { Maddi Varlık } \\
\text { Karlılık } \\
\text { Ortalaması } \\
2 \\
\end{array}$ & $\begin{array}{c}\text { Normal } \\
\text { Kazanç } \\
(1 X 2)=3\end{array}$ & $\begin{array}{c}\text { Ortalama } \\
\text { VÖK } \\
4\end{array}$ & $\begin{array}{l}\text { Brüt Ek } \\
\text { Kazanç } \\
(4-3)=5\end{array}$ \\
\hline \multirow[t]{4}{*}{2009} & \multirow{4}{*}{$\begin{array}{l}\text { Beşiktaş } \\
\text { Fenerbahçe } \\
\text { Galatasaray } \\
\text { Trabzonspor }\end{array}$} & & & & & Hesaplanamaz \\
\hline & & & & & & Hesaplanamaz \\
\hline & & 380.074 & $\% 421$ & 1.600 .111 & 60.973 .626 & 59.373.015 \\
\hline & & & & & & Hesaplanamaz \\
\hline \multirow[t]{4}{*}{2010} & \multirow{4}{*}{$\begin{array}{l}\text { Beşiktaş } \\
\text { Fenerbahçe } \\
\text { Galatasaray } \\
\text { Trabzonspor }\end{array}$} & & & & & Hesaplanamaz \\
\hline & & & & & & Hesaplanamaz \\
\hline & & 1.283 .319 & $\% 1253$ & 16.079 .987 & 60.377 .743 & 44.297 .756 \\
\hline & & & & & & Hesaplanamaz \\
\hline \multirow[t]{4}{*}{2011} & \multirow{4}{*}{$\begin{array}{l}\text { Beşiktaş } \\
\text { Fenerbahçe } \\
\text { Galatasaray } \\
\text { Trabzonspor }\end{array}$} & & & & & Hesaplanamaz \\
\hline & & 5.587 .007 & $\% 369$ & 20.616 .055 & 39.105 .082 & 18.489 .027 \\
\hline & & & & & & Hesaplanamaz \\
\hline & & 4.310 .388 & $\% 369$ & 15.904 .962 & 47.121 .771 & 31.216 .809 \\
\hline \multirow[t]{4}{*}{2012} & \multirow{4}{*}{$\begin{array}{l}\text { Beşiktaş } \\
\text { Fenerbahçe } \\
\text { Galatasaray } \\
\text { Trabzonspor }\end{array}$} & & & & & Hesaplanamaz \\
\hline & & 6.662 .425 & $(\% 15)$ & (999.363) & 40.043 .633 & 41.042.996 \\
\hline & & & & & & Hesaplanamaz \\
\hline & & 5.059 .849 & $(\% 15)$ & (758.977) & 46.021 .036 & 46.780 .013 \\
\hline \multirow[t]{4}{*}{2013} & \multirow{4}{*}{$\begin{array}{l}\text { Beşiktaş } \\
\text { Fenerbahçe } \\
\text { Galatasaray } \\
\text { Trabzonspor }\end{array}$} & & & & & Hesaplanamaz \\
\hline & & 6.887 .688 & $(\% 412)$ & $(28.377 .274)$ & 36.082 .850 & 64.460 .124 \\
\hline & & & & & & Hesaplanamaz \\
\hline & & 5.930 .530 & $(\% 412)$ & $(24.433 .783)$ & 6.196 .770 & 30.630 .553 \\
\hline \multirow[t]{4}{*}{2014} & \multirow{4}{*}{$\begin{array}{l}\text { Beşiktaş } \\
\text { Fenerbahçe } \\
\text { Galatasaray } \\
\text { Trabzonspor }\end{array}$} & & & & & Hesaplanamaz \\
\hline & & 9.680 .624 & $(\% 1126)$ & $(109.003 .826)$ & $(36.817 .977)$ & 72.185 .849 \\
\hline & & 10.729 .729 & (\%1126) & $(120.816 .748)$ & $(86.667 .489)$ & 34.149.259 \\
\hline & & 6.244 .119 & $(\% 1126)$ & $(70.308 .779)$ & $(35.465 .191)$ & 34.843.588 \\
\hline \multirow[t]{4}{*}{2015} & \multirow{4}{*}{$\begin{array}{l}\text { Beşiktaş } \\
\text { Fenerbahçe } \\
\text { Galatasaray } \\
\text { Trabzonspor }\end{array}$} & & & & & Hesaplanamaz \\
\hline & & 9.792 .821 & $(\% 2156)$ & $(211.133 .220)$ & $(99.377 .119)$ & 111.756.101 \\
\hline & & 9.811 .875 & $(\% 2156)$ & $(211.544 .025)$ & $(106.413 .182)$ & 105.130.843 \\
\hline & & 5.489 .929 & $(\% 2156)$ & $(118.362 .869)$ & $(72.061 .550)$ & 46.301 .319 \\
\hline \multirow[t]{4}{*}{2016} & \multirow{4}{*}{$\begin{array}{l}\text { Beşiktaş } \\
\text { Fenerbahçe } \\
\text { Galatasaray } \\
\text { Trabzonspor }\end{array}$} & & & & & Hesaplanamaz \\
\hline & & 11.551 .341 & $(\% 1697)$ & $(196.026 .256)$ & $(140.056 .240)$ & 55.970 .016 \\
\hline & & 9.046 .423 & (\%1697) & $(153.517 .798)$ & $(94.066 .916)$ & $\mathbf{5 9 . 4 5 0 . 8 8 2}$ \\
\hline & & & & & & Hesaplanamaz \\
\hline \multirow[t]{4}{*}{2017} & \multirow{4}{*}{$\begin{array}{l}\text { Beşiktaş } \\
\text { Fenerbahçe } \\
\text { Galatasaray } \\
\text { Trabzonspor }\end{array}$} & 90.839 .823 & $(\% 1408)$ & $(1.279 .024 .707)$ & $(60.398 .545)$ & 1.218.626.162 \\
\hline & & 13.284 .017 & $(\% 1408)$ & $(187.038 .959)$ & $(149.948 .623)$ & 37.090.330 \\
\hline & & & & & & Hesaplanamaz \\
\hline & & & & & & Hesaplanamaz \\
\hline \multirow[t]{4}{*}{2018} & \multirow{4}{*}{$\begin{array}{l}\text { Beşiktaş } \\
\text { Fenerbahçe } \\
\text { Galatasaray } \\
\text { Trabzonspor }\end{array}$} & 176.548 .487 & $(\% 1978)$ & $(3.492 .129 .072)$ & $(10.371 .279)$ & 3.481 .757 .793 \\
\hline & & 17.040 .818 & (\%1978) & $(337.067 .380)$ & $(181.188 .905)$ & 155.878 .475 \\
\hline & & 11.048 .717 & $(\% 1978)$ & $(218.543 .622)$ & $(196.616 .385)$ & 21.927 .237 \\
\hline & & & & & & Hesaplanamaz \\
\hline
\end{tabular}

6. Adım: Brüt kazanç, vergi oranı ile çarpılarak ek kazancın vergisi bulunur. Brüt kazançtan ek kazancın vergisi düşüldügünde ise net ek kazanç tutarı bulunur. Bu da maddi olmayan değerlere ait primdir. Bu durum aşağıdaki Tablo 11'de gösterilmiştir. 
Tablo 11. Spor Kulüplerinin Net Ek Kazanç Tutarlarının Hesaplanması

\begin{tabular}{|c|c|c|c|c|c|}
\hline & & $\begin{array}{c}\text { Brüt Kazanç } \\
\text { Tutarı } \\
1\end{array}$ & $\begin{array}{c}\text { Vergi Oranı } \\
2\end{array}$ & $\begin{array}{c}\text { Ek Kazancın } \\
\text { Vergisi } \\
(1 \mathrm{X} 2)=\mathbf{3}\end{array}$ & $\begin{array}{c}\text { Net Ek } \\
\text { Kazanç Tutarı } \\
(1-3)=4\end{array}$ \\
\hline \multirow[t]{4}{*}{2009} & \multirow{4}{*}{$\begin{array}{l}\text { Beşiktaş } \\
\text { Fenerbahçe } \\
\text { Galatasaray } \\
\text { Trabzonspor }\end{array}$} & & & & Hesaplanamaz \\
\hline & & & & & Hesaplanamaz \\
\hline & & 59.373 .015 & $\% 20$ & 11.874 .603 & 47.498.412 \\
\hline & & & & & Hesaplanamaz \\
\hline \multirow[t]{4}{*}{2010} & \multirow{4}{*}{$\begin{array}{l}\text { Beşiktaş } \\
\text { Fenerbahçe } \\
\text { Galatasaray } \\
\text { Trabzonspor }\end{array}$} & & & & Hesaplanamaz \\
\hline & & & & & Hesaplanamaz \\
\hline & & 44.297 .756 & $\% 20$ & 8.859 .551 & 35.438 .205 \\
\hline & & & & & Hesaplanamaz \\
\hline \multirow[t]{4}{*}{2011} & \multirow{4}{*}{$\begin{array}{l}\text { Beşiktaş } \\
\text { Fenerbahçe } \\
\text { Galatasaray } \\
\text { Trabzonspor }\end{array}$} & & & & Hesaplanamaz \\
\hline & & 18.489 .027 & $\% 20$ & 3.697 .805 & 14.791 .222 \\
\hline & & & & & Hesaplanamaz \\
\hline & & 31.216 .809 & $\% 20$ & 6.243 .361 & 24.973.448 \\
\hline \multirow[t]{4}{*}{2012} & \multirow{4}{*}{$\begin{array}{l}\text { Beşiktaş } \\
\text { Fenerbahçe } \\
\text { Galatasaray } \\
\text { Trabzonspor }\end{array}$} & & & & Hesaplanamaz \\
\hline & & 41.042 .996 & $\% 20$ & 8.208 .599 & 32.834.397 \\
\hline & & & & & Hesaplanamaz \\
\hline & & 46.780 .013 & $\% 20$ & 9.356 .002 & 37.424 .011 \\
\hline \multirow[t]{4}{*}{2013} & \multirow{4}{*}{$\begin{array}{l}\text { Beşiktaş } \\
\text { Fenerbahçe } \\
\text { Galatasaray } \\
\text { Trabzonspor }\end{array}$} & & & & Hesaplanamaz \\
\hline & & 64.460 .124 & $\% 20$ & 12.892 .024 & 51.568 .100 \\
\hline & & & & & Hesaplanamaz \\
\hline & & 30.630 .553 & $\% 20$ & 6.126 .110 & 24.504 .443 \\
\hline \multirow[t]{4}{*}{2014} & \multirow{4}{*}{$\begin{array}{l}\text { Beşiktaş } \\
\text { Fenerbahçe } \\
\text { Galatasaray } \\
\text { Trabzonspor }\end{array}$} & & & & Hesaplanamaz \\
\hline & & 72.185 .849 & $\% 20$ & 14.437 .169 & 57.748 .680 \\
\hline & & 34.149 .259 & $\% 20$ & 6.829 .851 & 27.319 .408 \\
\hline & & 34.843 .588 & $\% 20$ & 6.968 .717 & 27.874 .871 \\
\hline \multirow[t]{4}{*}{2015} & \multirow{4}{*}{$\begin{array}{l}\text { Beşiktaş } \\
\text { Fenerbahçe } \\
\text { Galatasaray } \\
\text { Trabzonspor }\end{array}$} & & & & Hesaplanamaz \\
\hline & & 111.756 .101 & $\% 20$ & 22.351 .220 & 88.404 .881 \\
\hline & & 105.130 .843 & $\% 20$ & 21.026 .168 & 84.104 .675 \\
\hline & & 46.301 .319 & $\% 20$ & 9.260 .263 & 37.041 .056 \\
\hline \multirow[t]{4}{*}{2016} & \multirow{4}{*}{$\begin{array}{l}\text { Beşiktaş } \\
\text { Fenerbahçe } \\
\text { Galatasaray } \\
\text { Trabzonspor }\end{array}$} & & & & Hesaplanamaz \\
\hline & & 55.970 .016 & $\% 20$ & 11.194 .003 & 44.776 .013 \\
\hline & & 59.450 .882 & $\% 20$ & 11.890 .176 & 47.560 .706 \\
\hline & & & & & Hesaplanamaz \\
\hline \multirow[t]{4}{*}{2017} & \multirow{4}{*}{$\begin{array}{l}\text { Beşiktaş } \\
\text { Fenerbahçe } \\
\text { Galatasaray } \\
\text { Trabzonspor }\end{array}$} & 1.218 .626 .162 & $\% 20$ & 243.725 .232 & 974.900 .839 \\
\hline & & 37.090 .330 & $\% 20$ & 7.418 .066 & 29.672.264 \\
\hline & & & & & Hesaplanamaz \\
\hline & & & & & Hesaplanamaz \\
\hline \multirow[t]{4}{*}{2018} & \multirow{4}{*}{$\begin{array}{l}\text { Beşiktaş } \\
\text { Fenerbahçe } \\
\text { Galatasaray } \\
\text { Trabzonspor }\end{array}$} & 3.481 .757 .793 & $\% 20$ & 696.351 .558 & 2.452.406.235 \\
\hline & & 155.878 .475 & $\% 20$ & 31.175 .695 & 124.702 .780 \\
\hline & & 21.927 .237 & $\% 20$ & 4.385 .447 & 17.541 .790 \\
\hline & & & & & Hesaplanamaz \\
\hline
\end{tabular}

7. Adım: Net ek kazanç tutarı ile işletmenin ağırlıklı ortalama sermaye maliyeti çarpılarak primin net bugünkü değeri hesaplanır. Bulunan değer işletmenin maddi olmayan varlıklarının hesaplanmamış değeridir ve bilançoda bulunmamaktadır. Spor kulüplerinin hesaplanan yıllara ait entelektüel sermaye değerleri Tablo 12'de gösterilmiştir.

Tablo 12. Spor Kulüplerinin Entelektüel Sermaye Tutarları

\begin{tabular}{|c|c|c|c|c|}
\hline & & $\begin{array}{c}\text { Net Ek Kazanç } \\
\text { Tutarı }\end{array}$ & $\begin{array}{l}\text { Ağırlık Ortalama } \\
\text { Sermaye Maliyeti }\end{array}$ & $\begin{array}{c}\text { Entelektüel Sermaye } \\
\text { Tutarları }\end{array}$ \\
\hline \multirow[t]{4}{*}{2009} & \multirow{4}{*}{$\begin{array}{l}\text { Beşiktaş } \\
\text { Fenerbahçe } \\
\text { Galatasaray } \\
\text { Trabzonspor }\end{array}$} & Hesaplanamaz & & Hesaplanamaz \\
\hline & & Hesaplanamaz & & Hesaplanamaz \\
\hline & & 47.498 .412 & $\% 25.25$ & 11.993 .349 \\
\hline & & Hesaplanamaz & & Hesaplanamaz \\
\hline
\end{tabular}




\begin{tabular}{|c|c|c|c|c|}
\hline \multirow[t]{4}{*}{2010} & \multirow{4}{*}{$\begin{array}{l}\text { Beşiktaş } \\
\text { Fenerbahçe } \\
\text { Galatasaray } \\
\text { Trabzonspor }\end{array}$} & \multicolumn{2}{|l|}{ Hesaplanamaz } & \multirow{2}{*}{$\begin{array}{l}\text { Hesaplanamaz } \\
\text { Hesaplanamaz }\end{array}$} \\
\hline & & Hesaplanamaz & & \\
\hline & & 35.438 .205 & $\% 24.48$ & 8.675 .272 \\
\hline & & Hesaplanamaz & & Hesaplanamaz \\
\hline \multirow[t]{4}{*}{2011} & Beşiktaş & Hesaplanamaz & & Hesaplanamaz \\
\hline & Fenerbahçe & 14.791 .222 & $\% 30$ & 6.041 .077 \\
\hline & Galatasaray & Hesaplanamaz & & Hesaplanamaz \\
\hline & Trabzonspor & 24.973 .448 & $\% 24.19$ & 6.243 .362 \\
\hline \multirow[t]{4}{*}{2012} & Beşiktaş & Hesaplanamaz & & Hesaplanamaz \\
\hline & Fenerbahçe & 32.834 .397 & $\% 24.73$ & 8.119 .946 \\
\hline & Galatasaray & Hesaplanamaz & & Hesaplanamaz \\
\hline & Trabzonspor & 37.424 .011 & $\% 25.78$ & 9.647 .910 \\
\hline \multirow[t]{4}{*}{2013} & Beşiktaş & Hesaplanamaz & & Hesaplanamaz \\
\hline & Fenerbahçe & 51.568 .100 & $\% 19.68$ & 10.148 .602 \\
\hline & Galatasaray & Hesaplanamaz & & Hesaplanamaz \\
\hline & Trabzonspor & 24.504 .443 & $(\% 17.81)$ & $(4.542 .341)$ \\
\hline \multirow[t]{4}{*}{2014} & Beşiktaş & Hesaplanamaz & & Hesaplanamaz \\
\hline & Fenerbahçe & 57.748 .680 & $\% 20,88$ & 12.057 .924 \\
\hline & Galatasaray & 27.319 .408 & $\% 36.42$ & 9.949 .728 \\
\hline & Trabzonspor & 27.874 .871 & $(\% 5.84)$ & $(1.627 .892)$ \\
\hline \multirow[t]{4}{*}{2015} & Beşiktaş & Hesaplanamaz & & Hesaplanamaz \\
\hline & Fenerbahçe & 88.404 .881 & $\% 23.82$ & 21.058 .042 \\
\hline & Galatasaray & 84.104 .675 & $\% 27.83$ & 23.406 .331 \\
\hline & Trabzonspor & 37.041 .056 & $\% 16.99$ & 6.293 .275 \\
\hline \multirow[t]{4}{*}{2016} & Beşiktaş & Hesaplanamaz & & Hesaplanamaz \\
\hline & Fenerbahçe & 44.776 .013 & $\% 34.93$ & 15.640 .261 \\
\hline & Galatasaray & 47.560 .706 & $\% 28.01$ & 13.321 .753 \\
\hline & Trabzonspor & Hesaplanamaz & & Hesaplanamaz \\
\hline \multirow[t]{4}{*}{2017} & Beşiktaş & 974.900 .839 & $\% 46.06$ & 449.039 .326 \\
\hline & Fenerbahçe & 29.672 .264 & $\% 44.39$ & 13.667 .044 \\
\hline & Galatasaray & Hesaplanamaz & & Hesaplanamaz \\
\hline & Trabzonspor & Hesaplanamaz & & Hesaplanamaz \\
\hline \multirow[t]{4}{*}{2018} & Beşiktaş & 2.452 .406 .235 & $\% 34.64$ & 880.689 .519 \\
\hline & Fenerbahçe & 124.702 .780 & $\% 54.46$ & 67.913 .133 \\
\hline & Galatasaray & 17.541 .790 & $\% 38.07$ & 6.678 .159 \\
\hline & Trabzonspor & Hesaplanamaz & & Hesaplanamaz \\
\hline
\end{tabular}

Tablo 13. Spor Kulüplerinin 2009-2018 Yılları Hes. Mad. Olm. Değ. Yön. Göre Entelektüel Sermaye Tutarı

\begin{tabular}{ccccc}
\hline & Beşiktaş & Fenerbahçe & Galatasaray & Trabzonspor \\
\hline $\mathbf{2 0 0 9}$ & - & - & 11.993 .349 & - \\
$\mathbf{2 0 1 0}$ & - & - & 8.675 .272 & - \\
\hline $\mathbf{2 0 1 1}$ & - & 4.437 .366 & - & 6.041 .077 \\
\hline $\mathbf{2 0 1 2}$ & - & 8.119 .946 & - & 9.647 .910 \\
\hline $\mathbf{2 0 1 3}$ & - & 10.148 .602 & - & $(4.542 .341)$ \\
\hline $\mathbf{2 0 1 4}$ & - & 12.057 .924 & 9.949 .728 & $(1.627 .892)$ \\
\hline $\mathbf{2 0 1 5}$ & - & 21.058 .042 & 23.406 .331 & 6.293 .275 \\
\hline $\mathbf{2 0 1 6}$ & - & 15.640 .261 & 13.321 .753 & - \\
\hline $\mathbf{2 0 1 7}$ & 449.039 .326 & 13.667 .044 & - & - \\
\hline $\mathbf{2 0 1 8}$ & 880.689 .519 & 67.913 .133 & 6.678 .159 & - \\
\hline
\end{tabular}

Entelektüel sermayeyi ölçmede en çok kullanılan yöntemlerden birisi hesaplanmış maddi olmayan değerler yöntemidir. Bu yöntem işletmelerin ES değerlerini dış etkenden en çok koruyan yöntemdir. Yöntemde 7 aşama izlenerek Tablo 13' de spor kulüplerinin hesaplanmış maddi olmayan değerler yöntemine göre 10 yıllık ES tutarları hesaplanmıştır.

Yöntemin 4. Aşamasında, sektörün üç yıl için gerçekleşmiş maddi varlıklar getiri oranı hesaplanır. Yöntem gereği hesaplamalara devam edilebilmesi için kulüplerinin maddi varlık getiri oranlarının sektörün ortalamasından yüksek olması gerekmektedir. Getiri oranları, sektör oranlarının altındaysa ilgili dönemlere ait ES tutarının hesaplanmasına devam edilemez. Bu sebeple spor kulüplerinin bazı dönemlere ait ES tutarları hesaplanamamiştır. 


\subsubsection{Ekonomik Katma Değer Yöntemi Aracılığıyla Entelektüiel Sermaye Ölçümü}

Finansal performans ölçüm yöntemi olarak bilinen Ekonomik Katma Değer (Economic Value Added EVA), işletme entelektüel sermayesinin ölçümünde de yararlanılan bir yöntemdir. Ekonomik katma değer, iki farklı yöntemle hesaplanabilmektedir. Bu yöntemlerle ilgili formüller ve açıklamalar aşağıdaki gibidir (Fletcher ve Smith, 2004: 2):

$$
\begin{gathered}
\text { EVA }=(\text { Faaliyet Karı }- \text { Düzeltilmiş Vergiler })- \\
(\text { A } \breve{g} \text { rllıklı Ortalama Sermaye Maliyeti } x \text { Yatırılan Sermaye }) \\
\text { EVA }=(\text { Yatırılan Sermaye Getirisi }- \text { Ağırlıklı Ortalama Sermaye Maliyeti }) x \text { Yatırılan Sermaye })
\end{gathered}
$$

Tablo 14. Galatasaray Spor Kulübü EVA Yöntemine Göre Entelektüel Sermaye Değeri

\begin{tabular}{cccccc}
\hline Faaliyet Kârı & $\begin{array}{c}\text { Düzeltilmiş } \\
\text { Vergiler }\end{array}$ & AOSM & $\begin{array}{c}\text { Yaturlan } \\
\text { Sermaye }\end{array}$ & $\begin{array}{c}\text { Entelektüel } \\
\text { Sermaye }\end{array}$ \\
\hline $\mathbf{2 0 0 9}$ & 51.945 .948 & 224.389 & 25.25 & 2.035 .000 & 51.207 .722 \\
\hline $\mathbf{2 0 1 0}$ & 30.853 .064 & 133.265 & 24.48 & 2.035 .000 & 30.221 .631 \\
\hline $\mathbf{2 0 1 1}$ & $(38.909 .929)$ & 9.783 & 27.49 & 2.035 .000 & -39.459 .567 \\
\hline $\mathbf{2 0 1 2}$ & 7.700 .460 & 129.064 & 27.86 & 2.788 .084 & 6.794 .636 \\
\hline $\mathbf{2 0 1 3}$ & $(64.470 .435)$ & 0 & 29.26 & 2.788 .084 & -65.283 .302 \\
\hline $\mathbf{2 0 1 4}$ & $(54.972 .174)$ & 0 & 36.42 & 13.940 .422 & -59.770 .467 \\
\hline $\mathbf{2 0 1 5}$ & $(82.469 .929)$ & $(705.467)$ & 27.83 & 21.645 .000 & -87.788 .265 \\
\hline $\mathbf{2 0 1 6}$ & 6.719 .222 & $(2.548 .043)$ & 28.01 & 21.645 .000 & -1.891 .764 \\
\hline $\mathbf{2 0 1 7}$ & $(148.539 .924)$ & $(1.608 .760)$ & 44.39 & 21.645 .000 & -156.539 .379 \\
\hline $\mathbf{2 0 1 8}$ & $(119.223 .934)$ & 4.096 .333 & 38.07 & 540.000 .000 & -320.705 .601 \\
\hline
\end{tabular}

Tablo 15. Spor Kulüplerinin 2009-2018 Yılları EVA Yöntemine Göre Entelektüel Sermaye Tutarı

\begin{tabular}{ccccc}
\hline & Beşiktaş & Fenerbahçe & Galatasaray & Trabzonspor \\
\hline $\mathbf{2 0 0 9}$ & -15.680 .995 & 40.226 .467 & 51.207 .722 & 21.534 .387 \\
\hline $\mathbf{2 0 1 0}$ & -42.084 .676 & 46.491 .152 & 30.221 .631 & 59.419 .361 \\
\hline $\mathbf{2 0 1 1}$ & -86.983 .914 & 83.583 .316 & -39.459 .567 & 60.343 .950 \\
\hline $\mathbf{2 0 1 3}$ & -115.521 .452 & -2.392 .239 & 6.794 .636 & -867.180 \\
\hline $\mathbf{2 0 1 4}$ & -59.272 .055 & -8.291 .399 & -65.283 .302 & -57.229 .671 \\
\hline $\mathbf{2 0 1 5}$ & -129.936 .356 & -93.942 .886 & -59.770 .467 & -47.275 .376 \\
\hline $\mathbf{2 0 1 6}$ & -88.279 .472 & -88.026 .448 & -87.788 .265 & -115.145 .216 \\
\hline $\mathbf{2 0 1 7}$ & -9.762 .836 & -51.967 .338 & -1.891 .764 & -56.909 .130 \\
\hline $\mathbf{2 0 1 8}$ & 25.927 .368 & -90.590 .555 & -156.539 .379 & -78.088 .722 \\
\hline
\end{tabular}

Tablo 15'de spor kulüplerinin 10 y1llık EVA yöntemine göre hesaplanan entelektüel sermaye tutarı birleştirilerek verilmiştir. Spor kulüplerinde EVA yöntemine en çok etki eden kalemlerin faaliyet karı ve yatırılan sermaye tutarları olduğu gözlenmektedir. Spor kulüplerinin yıllara ilişkin faaliyet faaliyet karı arttıkça ES tutarlarında da artış görülmektedir. Örneğin Tablo 21'de Fenerbahçe'nin 2013 yılına kadar faaliyetlerden kar elde ederken 2013 yılından itibaren faaliyetleri zarara yol açmıştır. Tablo 24 incelendiğinde ES tutarı da zarar oranı kadar azalmaya sebep olmuştur.

Spor kulüplerinin faaliyet karını ya da zararını etkileyen gelir kalemleri (şampiyonlar ligi ve UEFA gelirleri, futbolcu satış ve kiralama gelirleri, yayın gelirleri, lisanslı ürün satış gelirleri, maç hasılatları ve kombine kart loca geliri, sponsorluk ve reklam geliri vb.), gider kalemleri (ücret giderleri, amortisman ve tükenme payları, maç giderleri, futbolcu kiralama giderleri, seyahat giderleri, haklar değer düşüklüğü karşıllk gideri, futbolcu sözleşme fesih giderleri, menajerlik giderleri, federasyon giderleri, malzeme giderleri, personel giderleri, pazarlama giderleri, genel yönetim giderleri vb.)'dir.

\subsection{Değerlendirmeler}

Piyasa Değeri ve Defter Değeri Yöntemine İlișkin Değerlendirmeler

- Piyasa değeri ve defter değeri yöntemi işletmenin entelektüel sermaye değerini piyasa değerinin defter değerine oranlanmasıyla bulunur. 
- Hesaplanan oran 1'in üzerinde ve hesaplanan tutar pozitif çıkarsa işletmenin ES'nin varlığından bahsedilebilir.

- Hesaplanan oran 1'in altında olmasına rağmen hesaplanan tutar pozitif ise işletmenin ES'si vardır olarak değerlendirilebilir.

- Beşiktaş Kulübü'nün PD/DD oranı 10 yıllık periyotta 1'in altında kalmasına rağmen PD ve DD tutarı 10 yıllık periyotların çoğunda pozitif çıkmıştır. Hesaplanan tutarın dağılımı düzenli olmamasına rağmen FFP kriterlerinin uygulanmaya başladığı dönemden sonraki yıllarda ES varlığı daha fazladır. Beşiktaş Kulübü, FFP kriterlerini yerine getirmek amacıyla sermaye artırımı yolunu tercih eden kulübün bu sayede ES tutarları da pozitif çıkmıştır.

- Fenerbahçe Kulübü’nün PD/DD oran1 10 yıllık periyotta; 2014 y1lına kadar 1'in üstünde değer taşırken 2014 yılından sonra oran olarak ES varlığından bahsedilemez. Ancak kulüp defter değeri azaldıkça ES tutarı da aynı doğrultuda azalmıştır. FFP kriterlerini yerine getirmede başarısız olan kulübün ES tutarı da ilgili dönemlerde negatif yönlü hareket etmiştir.

- Galatasaray Kulübü'nün 10 yıllık periyotta PD/DD oranı ve tutarı incelendiğinde; her dönem 1'in altında kalan değer, tutar olarak sadece 2014 ve 2018 yılında pozitif çıkmıştır. 2018 yılında sermayesini büyük oranda artıran kulüp, ES tutarı olarak en verimli yıla sahiptir. Galatasaray'ın da FFP kriterlerini yerine getirmede başarılı olduğu söylenemez.

Dört spor kulübü içinde yıllar itibariyle ES tutarları arasındaki en az farka sahip kulüp Trabzonspor'dur. Kulübün son 10 y1l içinde sportif başarısı olmamasına rağmen kulüp yöneticilerinin, kulübün mali bozulmalara minimum şekilde izin vermesi, gereken önlemleri alması ES tutarındaki düzensizliklerin önüne geçmiştir.

Tobin Q Oranı Yöntemine İlişkin Değerlendirmeler

- Tobin q oranı şirketin piyasa değerini, toplam varlıkları yerine koyma maliyetine oranlanmasıyla bulunur. Ancak varlıkların yerine koyma maliyetinin hesaplanmasında güçlük yaşandığı için farklı formül tercih edilmiştir.

- Yöntemde q oranı 1'den ve diğerlerinden büyük olan kulüpler, benzer kulüplerden daha fazla kazanç elde etme kabiliyetlerini sahiptir. Aksi durumda ise kazanç elde etme kabiliyetlerinin düştüğü söylenebilir.

- Beşiktaş Kulübü'nün 10 yıllık dönemde q oranı incelendiğinde; her dönem 1'in üstünde çıkan orana ve azalış-artış-azalış trendine sahip q oranı elde edilmiştir. Oransal olarak FFP kriterlerini yerinde getirmede başarısız olan kulübün tutar olarak q değeri incelendiğinde FFP konusunda başarılı bir grafik çizdiği söylenebilir.

Fenerbahçe Kulübü'nün 10 yıllık dönemde q oranı ve tutarı incelendiğinde; diğer kulüplere kıyasla en başarılı kulüp olduğu görünmektedir. Oran olarak en başarılı dönemleri 2009 ve 2010 yılında olan kulübün q değeri incelendiğinde yıllar itibariyle büyük tutarlarda farkların olmadığı 10 yıllık periyot sergilemiştir. Kulüp, FFP talimatlarına karşı hem oran hem tutar olarak düzenli bir grafik çizememiştir.

- Galatasaray Kulübü'nün 10 yıllık dönemde q oranı ve tutarı incelendiğinde; en başarısız kulüp olarak dikkat çekmektedir. Kulüp oransal olarak FFP talimatlarını yerine getirmede başarılı olmasında rağmen tutarsal olarak başarısız bir grafik çizmiştir. En büyük ES tutarını yakalığı 2018 yılı en büyük sermaye artırımına gittiği yıl olarak da bilinmektedir.

- $\quad$ Spor kulüplerinin FFP talimatlarını yerine getirmede en başarılı kulüp Trabzonspor kulübüdür. Kulüp hem oransal olarak hem tutar olarak FFP kurallarına her y1l artış trendiyle yerine getirmiştir.

\section{Hesaplanmıș Maddi Olmayan Değer Yöntemine İlișkin Değerlendirmeler}

- $\quad$ Bu yöntemin göze çarpan ilk avantajı borsaya kote olmayan bir işletmeye de uygulanabilmesidir. Bir işletme TCMB'den elde ettiği sektör ortalamaları ile kendi hesaplamasını yapabilir. Ayrıca bir piyasa verisine ihtiyaç duymaz.

Hesaplama PD/DD ve q oranının hesaplanmasına göre daha uzundur. Fakat yöntem ES tutar olarak hesaplar ve pozitif değerdedir. Bu, ifade gerçeğe daha yakındır.

- Yöntem, tüm sektör şirketlerini göz önüne aldığ1 için işletmenin sektördeki konumunun belirlenmesinde faydalıdır. Ayrıca başka sektörler ile karşılaştırma yapılarak piyasadaki yeri hakkında fikir edinilebilir.

- Yöntemin tüm ülke genelindeki şirketleri kapsaması işletmeyi ortalama bir şirket ile kıyaslamaya itecektir. Fakat sektördeki başarılı şirketler bu kıyaslamanın üzerinde bir değerlendirme yapmak zorundadır.

- Hesaplanmış maddi olmayan değerleri yöntemi dış faktörlerden en az etkilenen yöntem olduğunda en doğru sonuçlar da bu yöntemden alınmaktadır. 
- Ancak spor kulüplerinin 10 yıllık ES tutarı hesaplandığında, kulüplerin bazı yıllarda hesaplama yapılması mümkün olmadığı için herhangi bir yorum yapmak ya da karşılaştırma yapmak uygun olmamaktadır.

\section{Ekonomik Katma Değer Yöntemine İlișkin Değerlendirmeler}

- $\quad$ Entelektüel sermayeyi işletme bazında ölçen yöntemler ele alındığında spor kulüpleri adına en doğru sonuçları veren yöntem EVA yöntemidir.

Çünkü FFP talimatlarının temelini denk bütçe (gelir ve gider dengesi) ve sermaye yapılanması (eksi öz sermayenin olmaması) oluşturmakta, bu yöntemin hesaplanmasında da faaliyet karı ve sermaye özellikle dikkate alınmaktadır.

- Yöntem aynı zamanda finansal performansı ölçmeye yönelik bir yöntemdir. UEFA'nın FFP kurallarını getirmedeki amacı da kulüplerin finansal performanslarını artırmaktır.

- Böylece EVA yöntemi spor kulüplerinin ES değerlerine FFP'in etkisini ölçen en önemli yöntem olmaktadir.

- Beşiktaş Kulübü'nün 10 yıllık ES tutarı incelendiğinde; kulübün 2014 yılından sonra FFP talimatlarını başarıyla yerine getirdiği söylenebilir. 2009-2014 yılları arasında ES tutarı negatif yönde artış gösteren kulübün, FFP uygulaması geldiği yıldan itibaren ES tutarı pozitif yönlü artışa geçmiştir.

Fenerbahçe Kulübü'nün 10 y1llık ES tutarı incelendiğinde; ES tutarı 2009 yılından itibaren sürekli azalış göstermiş̧ir. FFP kuralarını yerine getirmede ise başarısız bir grafik çizmiştir. Kulübün başarısız grafik çizmesinin temel sebebi 3 Temmuz 2011 yılında yaşadığı siyasi olaylara bağlanabilir. Bu tarihten itibaren faaliyet karı azalış trendi gösteren kulüp dolayısıyla ES değeri olarak da azalış sergilemiştir.

Galatasaray Kulübü’nün 10 yıllık ES tutarı incelendiğinde; Fenerbahçe Kulübü’nün ES tutarına ilişkin değerlendirmelerin Galatasaray Kulübü için de geçerli olduğu kanısına varılabilir.

Trabzonspor Kulübü dört kulüp içinde en başarısız ES değerine sahip kulüptür. Aynı şekilde FFP talimatlarını yerine getirmede olumsuzluk yaşayan kulüp, en verimli dönemini 2009-2011 yılları arasında yaşamıştır.

- $\quad$ EVA yöntemine göre spor kulüpleri, FFP uygulamasında başarısız olmuşlardır.

- Başarısızlığın temel sebebi ise 2014'ten itibaren ülkemizde yaşanan hızlı kur artışıyla birlikte maliyetlerin artarak faaliyet karlarının azalmasıdır.

\section{SONUÇ}

Bilgi ve teknoloji ağırlıklı günümüz ekonomik yapısı içerisinde, hızla değişen ekonomik, sosyal ve politik çevresine ayak uyduramayan ve rekabet edemeyen işletmeler varlığını sürdürememektedir. Rakiplere karşı rekabet üstünlüğü elde etmek, rakip işletmelerden haberdar olmak kadar kendi işletmemizi de çok iyi tanımamızı gerektirmektedir. 90'lardan sonra sıkça üzerinde durulan ama aslında temelleri çok öncelere dayanan entelektüel sermaye, işletmelerin rekabet üstünlüğünü elde edebilmeleri için kendi haklarında bilmeleri gereken en önemli kavram haline gelmiştir. Fiziki yapının, varlıkların yanı sıra işletmenin sahip olduğu ve o işletmeye rekabet avantajı sağlayacak olan bütün maddi olmayan varlıklar entelektüel sermaye olarak tanımlanmıştır.

Futbol ekonomisinin en önemli aktörlerinden futbol kulüplerinin son y1llarda göstermiş olduğu kötü mali performanslar, futbol ekonomisinin tüm bileşenlerini tehdit etmeye başlamıştır. Futbol kulüplerinin harcamalarını gelirlerinin çok üstünde yapması maaş ve borç yüklerinin artmasına, artan borç yükü karlarının ciddi oranda azalmasına yol açmıştır. Gelirlerinin büyük kısmını finansal giderlerine harcayan birçok futbol kulübünün ortaya çıkması mali disiplinden açık bir şekilde uzaklaşıldığının göstergesi haline gelmiştir.

Avrupa Futbolu'nun en büyük düzenleyici ve denetleyici kurumu olan UEFA (the Union of European Football Associations), 2004-2005 sezonundan sonra geçerli olmak üzere ilk başta kulüp lisanslama kriterlerini getirmiştir. Bu uygulama ile tesisleşme, yönetim ve hukuki konularda ciddi başarılar yakalayan UEFA, mali kriterlerin yanına "Finansal Fair Play" olarak adlandırdığı birçok kriter eklemiştir. FFP kriterleri ile temelde gelir-gider denkliğini sağlama amacı güden UEFA, futbol kulüplerinin mali yapılarını güçlendirmek adına birçok kurallar getirmiştir.

Her işletmede olduğu gibi spor kulüpleri de entelektüel sermayeye ve entelektüel sermayenin bileşenleri ola insan sermayesi, müşteri sermayesi ve ilişki sermayesine sahip birer işletme konumundadır. UEFA'nın FFP kapsamında getirdiği mali disiplinin sağlanmasına ilişkin kurallar futbol kulüplerinin de entelektüel sermaye değerlerini etkilemiştir.

$\mathrm{Bu}$ açıklamalar 1şığında çalışmamızda futbol kulüplerinin mali yapılarını güçlendirmek amacıyla UEFA'nın getirdiği FFP kurallarının kulüplerinin entelektüel sermayelerine etkisi ölçülmüştür. Çalışmamızın kapsamına BISTT'de yer alan Beşiktaş, Fenerbahçe, Galatasaray ve Trabzonspor kulüpleri dahil edilmiştir. 
Çalışmamızda parasal bir değer tespit eden işletme bazında ölçüm yöntemleri kullanılmıştır. İşletme bazında ölçüm yöntemlerinden (Piyasa Değeri ve Defter Değeri, Tobin'in Q Değeri, Hesaplanmış Maddi Olmayan Değer ve Ekonomik Katma Değer Yöntemi) her biri ile spor kulüplerinin 10 ylllık entelektüel sermaye değerleri ölçülmüş FFP kriterlerinin etkisi saptanmıştır.

Entelektüel sermayeyi işletme bazında ölçen yöntemlerden en anlamlı bulgular Ekonomik Katma Değeri yönteminden elde edilmiştir. Futbol kulüplerinin ES tutarları düzenli olarak ölçülemediğinden kesin sonuçlara varılması mümkün olmamaktadır. Piyasa Değeri ve Defter Değeri yöntemi ile Tobin'in Q Oranı yönteminde, elde edilen oranlar ve tutarlar farklı olduğundan spor sektörünün ES değerlerini ve tutarlarını ölçmede anlamsız kalmaktadır.

Buna Ekonomik Katma Değeri yöntemine göre Beşiktaş, Fenerbahçe, Galatasaray ve Trabzonspor'un ES tutarları FFP kapsamında değerlendirildiğinde şu sonuçlar ortaya çıkmıştır;

- Son dönemlerde ülkemizde yaşanan kur artışı spor kulüplerinin mali yapısını bozmuş, dolasıyla ES tutarlarını negatif yönde etkilemiştir.

- Kulüplerin yaptığı borçlanmalar sermaye yapısını bozmakta, faaliyet karlarını azaltmaktadır. $\mathrm{Bu}$ sebeple FFP kriterlerini yerine getirmediğinden UEFA'nın yaptırımlarıyla karşılaşmaktadırlar. Faaliyet karı azalan kulüplerin ES tutarları da aynı oranda azalmaktadır.

- Kulüpler, gelirlerin giderleri karşılamaması nedeniyle zaman içinde oluşan zararları karşılayabilmek amacıyla sermaye artırımına gitmektedirler. Sermaye artışı kulüplerin ES yapısını bozmaktadır.

- Finansal Fair Play kapsamında öz kaynak yapısını güçlendirmek ve zarar yapan kulüplerde "kabul edilebilir zarar"1 aşan kısmın ilgili kulüplerce giderilmesi zorunluluğundan dolayı sermaye artışı yapmak zorundadırlar. Bu durum ES tutarlarında azaltıcı rol oynamaktadır.

- Kulüpler, elde ettikleri sportif başarılar doğrultusunda gelir elde edebilmekte bu durum da mali yapılarını ve ES güçlendirmektedir. 


\section{KAYNAKÇA}

Andriessen, D., \& Stam, C. D. (2005, January). Intellectual capital of the European Union. In McOaster world congress on the management of intellectual capital and innovation (pp. 19-21).

Bontis, N. (1998). Intellectual capital: an exploratory study that develops measures and models. Management decision, 36(2), 63-76.

Cañibano, L., Garcia-Ayuso, M., \& Sánchez, M. P. (1999). The value relevance and managerial implications of intangibles: A literature review. Proyecto Meritum, 4-57.

Chung, H. K., \& Pruitt, S.W. (1994). A simple approximation of Tobin Q. Financial Management, 23(3), $70-74$.

Çetin A. (2005). Entelektüel sermaye ve ölçülmesi. Marmara İIBF Dergisi, 20(1), 359-378.

Tomé, E., Naidenova, I., \& Oskolkova, M. (2014). Personal welfare and intellectual capital: the case of football coaches. Journal of Intellectual Capital, 15(1), 189-202.

Fletcher, H. D., \& Smith, D. B. (2004). Managıng for value: developıng a performance measurement system integratıng economic value added and the balanced scorecard in strategic planning. Journal of Business Strategies, 21(1), 117.

Roos, G., \& Roos, J. (1997). Measuring your company's intellectual performance. Long range planning, 30(3), 413-426.

Gurel, S., Dagli Ekmekci, Y. ve Küçükkaplan, İ. (2012). Measuring intellectual capital for football clubs: evidence from turkish first division football league. Pamukkale Spor Bilimleri Dergisi, 4(1), 36-47.

Hacırüstemoğlu, R., Şakrak, M. ve Demir, V. (2002). Etkin performans ölçüm aracı (EVA)(Ekonomik Katma DeğerEkonomik Kâr Yaklaşımı). Mali Çözüm Dergisi, (59), 1-9.

Horasan, E. (2013). Spor kulüplerinde entelektüel sermaye bileşeni olarak sporcuların değeri ve mali tablolara yansıtılması (Yayınlanmamış Doktora Tezi). Marmara Üniversitesi SBE, İstanbul.

Hunter, L. (2002). Intellectual capital: accumulation and appropriation, In Melbourne Institute working paper series, Vol. Melbourne Institute of Applied Economic and Social Research University of Melbourne, 22/02.

Perechuda, I. (2016). Market value, book value and intellectual capital value in case of football clubs listed on stock exchange. In Proceedings 8th International Scientific Conference Managing and Modelling of Financial Risks (Vol. 3, pp. 798-806). VŠB-TU of Ostrava, Faculty of Economics, Department of Finance.

Itami, H., \& Roehl, T. W. (1991). Mobilizing invisible assets. Harvard University Press, Cambridge, MA, ABD.

Kamuoyu Aydınlatma Platformu (KAP), (2019, 21 Ağustos). Erişim adresi: https://www.kap.org.tr/tr/Sektorler

Koole, M., \& de Roos, E. (2010, March). Strategic Asset-Base Valuation and Evaluation Framework With an Intellectual Capital Perspective. In The Proceedings of the 2nd European Conference on Intellectual Capital (p. 346), ISCTE - Lisbon University Institute, Lisbon

Lardo, A., Dumay, J., Trequattrini, R., \& Russo, G. (2017). Social media networks as drivers for intellectual capital disclosure: Evidence from professional football clubs. Journal of Intellectual Capital, 18(1), 63-80.

Leitão, J., \& Baptista, J. (2019). Intellectual capital assets and brand value of English football clubs. International Journal of Sport Management and Marketing, 19(1-2), 8-34.

Özevren, M. ve Yıldız, S. (2010). Entelektüel sermaye ölme yöntemleri ve kriterlerinin belirlenmesi üzerine bir araştırma. Marmara Üniversitesi İktisadi ve İdari Bilimler Dergisi, 29(2), 275-289.

Dimitropoulos, P. E., \& Koumanakos, E. (2015). Intellectual capital and profitability in European football clubs. International Journal of Accounting, Auditing and Performance Evaluation, 11(2), 202-220.

Ray, R. (2001). Economic value added: theory, evidence, A missing link. Review of Business, 22(1/2), 66-70.

Ricci, F., Scafarto, V., Celenza, D., \& Gilvari, I. S. (2015). Intellectual Capital and Business Performance in Professional Football Clubs: Evidence From a Longitudinal Analysis. Journal of Modern Accounting and Auditing, 11(9), 450465.

Shareef, F., \& Davey, H. (2005). Accounting for intellectual capital: evidence from listed English football clubs. Journal of Applied Accounting Research, 7(3), 78-116.

Stewart, B. (2009). EVA momentum: the one ratio that tells the whole story. Journal of Applied Corporate Finance, 21(2), 74-86.

Stewart, T. A. (1997). Intellectual capital: The New Wealt of Organizations. New York: Double day/ Currency, 1-15.

Yaşar, N. N., Işık, M. ve Çalışır, F. (2015). Intellectual capital efficiency: the case of football clubs. In Procedia-Social and Behavioral Sciences, 207, 354-362. 